\title{
Ultrafine sea spray aerosol over the southeastern Pacific: open-ocean contributions to marine boundary layer CCN
}

\author{
R. Blot ${ }^{1}$, A. D. Clarke ${ }^{1,2}$, S. Freitag ${ }^{2}$, V. Kapustin ${ }^{1}$, S. G. Howell ${ }^{1}$, J. B. Jensen ${ }^{3}$, L. M. Shank ${ }^{1, *}$, C. S. McNaughton ${ }^{1, * *}$, \\ and V. Brekhovskikh ${ }^{1}$ \\ ${ }^{1}$ Department of Oceanography, University of Hawaii at Manoa, Hawaii, HI 96816, USA \\ ${ }^{2}$ Department of Meteorology, University of Hawaii at Manoa, Hawaii, HI 96816, USA \\ ${ }^{3}$ NCAR/EOL, Boulder, CO, USA \\ * now at: Pearl Harbor Naval Shipyard, Quality Assurance Division, JBPHH, HI 96860, USA \\ ** now at: Golder Associates Ltd., Saskatoon, SK, Canada
}

Correspondence to: A. D. Clarke (tclarke@ soest.hawaii.edu)

Received: 18 January 2013 - Published in Atmos. Chem. Phys. Discuss.: 4 February 2013

Revised: 6 June 2013 - Accepted: 19 June 2013 - Published: 30 July 2013

\begin{abstract}
Accurate measurements of natural aerosol emissions over the ocean are needed to estimate the anthropogenic impact on the environment. In this study, we measured sea spray aerosol (SSA) concentrations with diameters larger than $0.040 \mu \mathrm{m}$ produced by open-ocean breaking waves over the SEP (southeastern Pacific). Robust statistics were established through repeated airborne flights over $1000 \mathrm{~km}$ along $20^{\circ} \mathrm{S}$ from the coastline of Chile to $85^{\circ} \mathrm{W}$ during VOCALS-REx (VAMOS Ocean-Cloud-AtmosphereLand-Study Regional Experiment). Non-volatile SSA number concentrations were inferred using a thermally resolved technique constrained for clean conditions with an Ångström exponent below 0.5 , black carbon mass concentration at values lower than $15 \mathrm{ng} \mathrm{m}^{-3}$ and organic aerosol concentration less than $0.02 \mu \mathrm{g} \mathrm{m}^{-3}$. We found that number concentrations of SSAs active as cloud condensation nuclei (CCN) for a supersaturation of $0.25 \%$ varied between 17 and $36 \mathrm{~cm}^{-3}$, but these did not increase with the increasing mean wind speed typically observed further offshore along $20^{\circ} \mathrm{S}$. Concurrent increases in mean offshore precipitation rate in excess of about $1 \mathrm{mmd}^{-1}$ indicate that scavenging of SSAs by precipitation exceeds increases in production at wind speeds above about $8 \mathrm{~m} \mathrm{~s}^{-1}$. This demonstrates the critical role of precipitation as a major sink of SSA over the remote ocean. Finally, we found that under clean conditions and for estimated stratus supersaturations between 0.20 and $0.43 \%$, SSA represented about $20 \%$ of the total potential $\mathrm{CCN}$ along $20^{\circ} \mathrm{S}$.
\end{abstract}

\section{Motivation}

It is well recognized that aerosols contribute significantly to the earth's radiative budget due to their ability to scatter and absorb solar radiation (Ramanathan et al., 2001) (direct effect) or through modifying cloud albedo (Twomey, 1974) and precipitation (Stevens and Feingold, 2009) (indirect effect). Many studies have focused on the modifications induced by anthropogenic aerosols; however, large uncertainties also remain in natural emissions which contribute to the clean unperturbed atmosphere (Yang et al., 2012; De Leeuw et al., 2011).

The ocean represents the most significant natural aerosol source on Earth by mass (Kiehl and Rodhe, 1995). These are typically primary sea spray aerosols (SSAs) released via bursting processes of air bubbles originated from wind induced breaking waves (Blanchard and Woodcock, 1957) and secondary aerosol formed by gas-to-particle conversion processes of dimethyl sulfide vapors (DMS) (Andreae and Raemdonck, 1983). In this study, SSAs represent all the inorganic materials (sea salt), organic matter (Woodcock, 1948; O'Dowd et al., 2004) and other surface active materials (exopolymer) (Blanchard, 1964; Bigg and Leck, 2008) that can be incorporated into aerosol from bursting air bubbles at the ocean surface.

In the marine boundary layer (MBL), the ocean is not the only source of aerosol. In fact, marine aerosol consists of a complex mix of constituents with various origins 
(Heintzenberg et al., 2000). Natural and anthropogenic aerosols can be entrained from the free troposphere (FT) due to large-scale subsidence (Clarke et al., 1998) and particles transported from continents into the MBL can also constitute a significant fraction of the marine aerosol. The latter are typically dust aerosols (Prospero and Carlson, 1972) and natural organic aerosols as well as anthropogenic soot particles (or black carbon, BC) (Clarke, 1989), sulfates (Savole and Prospero, 1982) and nitrates (Prospero and Savoie, 1989).

In the "clean" MBL, free of dust and pollution, the total mass of marine aerosols is dominated by coarse SSAs $\left(d_{\text {dry }}{ }^{1} \geq 1 \mu \mathrm{m}\right)$. These are mostly sea salt particles (Murphy et al., 1998) and represent a major contribution to scattering of electromagnetic radiation over the ocean (Lewis and Schwartz, 2004). Coarse SSAs are shown to scatter more than $75 \%$ of the total incoming light (Murphy et al., 1998). On the other hand, the clean marine aerosol submicron mass $\left(d_{\mathrm{dry}} \leq 1 \mu \mathrm{m}\right)$ is dominated by natural volatile sulfate species (Clarke, 1991). In clean regions, the latter account for most of the aerosol total number and often most of those active as cloud condensation nuclei (CCN).

Early studies usually focused on the inorganic SSA larger than about $0.2 \mu \mathrm{m}$ in consideration of their influence on atmospheric light propagation as well as their effect on the atmospheric sulfur cycle (O'Dowd et al., 1997). Currently there is a growing interest in establishing the number of smaller SSAs over the ocean and their role as CCN. The latter SSA and sulfate aerosol can activate as $\mathrm{CCN}$ at low supersaturations in stratus clouds due to their high hygroscopicity. Their increased size when activated facilitates both gas-to-particle conversion and collision coalescence such that they grow to larger dry sizes upon evaporation. This leads to a size separation between previously activated and unactivated sizes that is recognized as a Hoppel minimum (Hoppel et al., 1986). Therefore, understanding the CCN in these clouds requires an understanding of the contributions of SSA and other aerosols to sizes larger than the Hoppel minimum for such clouds, typically about $50-80 \mathrm{~nm}$.

Unfortunately, the size-resolved mass, number and chemistry of ultrafine SSA $\left(d_{\text {dry }} \leq 0.1 \mu \mathrm{m}\right)$ is still poorly characterized due to signal-to-noise limitations for chemical techniques at low mass concentrations and because volatile sulfates, organics and other anthropogenic aerosols are often mixed and difficult to resolve quantitatively. During the last two decades, evidence from laboratory experiments (Mårtensson et al., 2003; Sellegri et al., 2006) and field campaigns (Murphy et al., 1998; Clarke and Kapustin, 2003; Zhou et al., 2001) showed that bubble-bursting processes produce SSAs as small as $0.01 \mu \mathrm{m}$ but the shape of the number size distribution and the chemical composition associated with these ultrafine SSAs are still uncertain. It remains controversial that these dominate the total number of SSAs and that sea salts represent a major component in this fraction.

${ }^{1}$ Diameter of a dry aerosol particle $\left(d_{\text {dry }}\right)$.
Recent studies (Cavalli et al., 2004; O'Dowd et al., 2004) showed that over the North Atlantic Ocean organic matter issued from biogenic activity also transfers to the atmosphere via bubble-bursting. According to the authors, these can seasonally dominate the mass of submicrometer marine aerosols with very little contribution from the sea salts. Also more recently Bigg and Leck (2008) argue strongly for a non-sea-salt predominance in the SSA ultrafine fraction. Airborne gels and aggregates of various exopolymers, viruses and bacteria were found common in aerosol in the high arctic (Leck and Bigg, 2005) with number size distribution peaking at $0.3 \mu \mathrm{m}$ and no mixture with sea salt. On the contrary, Shank et al. (2012) found negligible contribution to the organic aerosols from natural ocean sources over the southeast $\mathrm{Pa}-$ cific (SEP). Moreover, using a thermal analytical technique, Clarke et al. (2006) showed that ultrafine SSA from coastal breaking waves peaked near $0.03 \mu \mathrm{m}$ and that sizes above $0.09 \mu \mathrm{m}$ were chemically identified as sea salt while humidification response of sizes down to $0.04 \mu \mathrm{m}$ behaved like sea salt.

However, for cloud microphysics the chemical composition of SSA matters only if it influences the particle hygroscopicity and the critical size at which SSA activates. Recently, Bates et al. (2012) confirmed that ultrafine SSAs, isolated directly from bubble-breaking just above the sea surface, grow similarly to pure sodium chloride aerosols at low supersaturations near $0.25 \%$. Consequently, it is possible to only focus on SSA sizes and number concentrations that can be activated to become a cloud droplet.

The understanding of SSA production and lifetime in the MBL is also fairly complex. Many studies note that concentrations of coarse SSA are well correlated with the surface wind speed, which is considered as the major parameter for SSA production (Lewis and Schwartz, 2004). But, large scatter in the data is often observed for submicrometer particles. Once injected into the atmosphere, size and concentration evolution is affected by the thermodynamics (condensation, evaporation), chemistry (heterogeneous chemistry), microphysics (cloud processes) and mixing linked to the dynamic of the MBL (buoyancy, inversion height). Spatial assessments of flight data over $60 \mathrm{~km}$ circles in clean regions have revealed a large horizontal and vertical variation of the SSA over the ocean (Shinozuka et al., 2004). Large uncertainties remain in how concentrations are affected by dilution (turbulent mixing, entrainment, inversion height) and removal (wet and dry deposition) processes.

In this study, we present SSA number concentrations measured in the MBL during the VAMOS ${ }^{2}$ Ocean-CloudAtmosphere-Land-Study Regional Experiment (VOCALSREx) over the the southeast Pacific (SEP). Using thermally resolved airborne measurements, we confirm that open-ocean SSAs effective as $\mathrm{CCN}$ are produced by

\footnotetext{
${ }^{2}$ Variability of the American Monsoon Systems.
} 


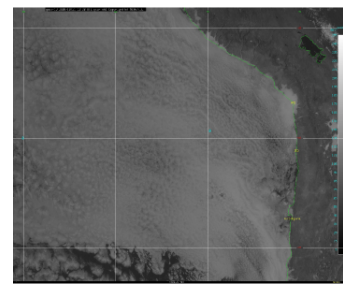

(a) Solid cloud deck

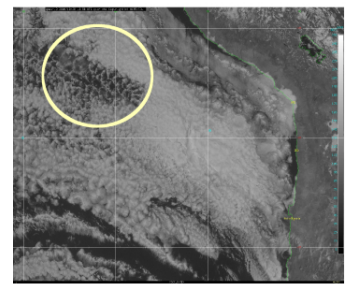

(b) POCs over the SEP

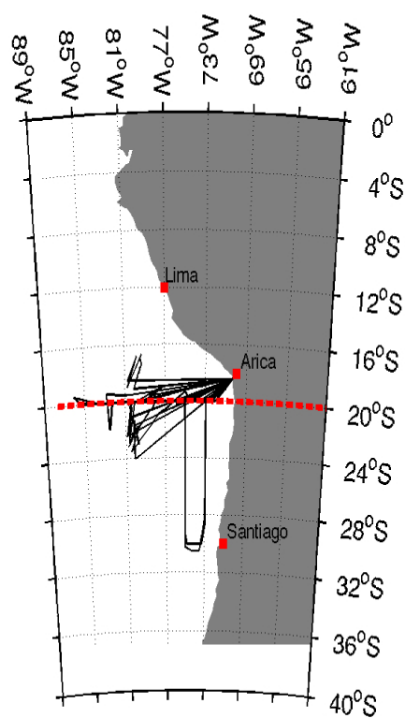

(c) C-130 flight tracks

Fig. 1. (a) GOES visible imagery. Solid cloud deck observed during RF03 at 12:28 UTC. (b) POCs during RF02 at 17:15 UTC. (c) $\mathrm{C}-130$ flight tracks in the MBL during VOCALS-REx. The red line highlights the $20^{\circ} \mathrm{S}$ latitude.

bubble-bursting processes and we show that ultrafine SSAs at least as small as $0.040 \mu \mathrm{m}$ are introduced into the MBL.

The first and second part of this paper describe the instrumentation and the method used. We use strict criteria to remove data dominated by pollution in order to work only with clean marine size distributions. Evidence of ultrafine SSA is shown by comparing non-volatile aerosol numbers measured at high temperature and scattering coefficients at $700 \mathrm{~nm}$ and $550 \mathrm{~nm}$, which are known to vary strongly with the coarse SSAs.

In a third part, we apply our method to study the variability of MBL SSA number concentrations at the $20^{\circ} \mathrm{S}$ latitude over the SEP. We also estimate their contribution to the clean MBL CCN numbers.

\section{Campaign and measurements}

\subsection{VOCALS-REx}

This study is based on data acquired during VOCALS-REx from 12 October to 15 November 2008 over the SEP. In total, five research aircraft, two ships and two surface sites in northern Chile were involved. The SEP presents a semipermanent stratocumulus cloud deck (Fig. 1a) that is not well represented in Global Climate Model (GCM) due to the poorly understood interactions between aerosol, cloud and precipitation in this region (Wood et al., 2011b). Drizzle in extended stratus offshore appears to favor the formation of pockets of open cells (POCs) (Wood et al., 2008) (Fig. 1b),

but the processes which maintained the POCs within the adjacent stratocumulus clouds, including the role of $\mathrm{CCN}$, are still the subject of investigations. A complete description of VOCALS-REx instrumentation can be found in Wood et al. (2011b).

The measurements used here were performed aboard the National Science Foundation (NSF) and the National Center for Atmospheric Research (NCAR) C-130 aircraft during 14 research flights (RF) over the SEP. Figure 1c shows the area covered by the aircraft over the SEP ocean. A first mission objective was to develop statistics on the aerosol properties and cloud microphysics for repeated flights along $20^{\circ} \mathrm{S}$ with legs in the surface mixed layer (ML), the cloud layer (also called the buffer layer - BF) and the free troposphere between 71 and $86^{\circ} \mathrm{W}$. A second objective was to characterize existing drifting POCs using stacked legs. A third mission type consisted of two pollution survey missions along the coast of Chile from 20 to $30^{\circ} \mathrm{S}$ following 73 and $75^{\circ} \mathrm{W}$ on the return. The non-POC missions generally consisted of 10 to 15 min horizontal legs in the MBL, BF and FT interspersed with vertical profiles up to $4 \mathrm{~km}$.

\subsection{Inlet}

Ambient aerosol concentrations were sampled using the University of Hawai'i shrouded passive solid diffuser inlet (SDI) (McNaughton et al., 2007). Then, particles went through to flow splitters and tubing diameters selected to minimize particle losses to various instruments inside the $\mathrm{C}-130$. The SDI has an aerodynamic diameter $50 \%$ cutoff of $5.0 \mu \mathrm{m}$ at $85 \%$ relative humidity $(\mathrm{RH})$. Assuming a spherical (shape factor $\chi=1)$ wet sea salt aerosol $(\mathrm{RH}=85 \%)$ with a density $\rho=1.15 \mathrm{~g} \mathrm{~cm}^{-3}$ and taking a humidity growth factor of 2.15 (Tang et al., 1997), the $50 \%$ dry diameter cutoff $(\mathrm{RH} \leq 40 \%)$ is estimated to be about $2.16 \mu \mathrm{m}$.

Figure 2 shows the superposition of dry volume size distributions measured inside the aircraft behind the SDI along with distributions measured using the Giant Nuclei Impactor (GNI). The latter instrument consists of polycarbonate slides exposed directly to aerosols from the air-stream outside the $\mathrm{C}-130$. Each slide is analyzed in a humidity controlled glass chamber $(\mathrm{RH}=90 \%)$ using an optical microscope mounted with two cameras and corrected to dry sizes. Due to a very large sample volume $\left(10 \mathrm{Ls}^{-1}\right)$ at typical low-altitude aircraft speed $\left(105 \mathrm{~m} \mathrm{~s}^{-1}\right)$, the GNI provides accurate measurements $( \pm 10 \%)$ of giant nuclei in the dry sizes range of about $1.6 \mu \mathrm{m}$ up to several tens of micrometers. These two very different measurement approaches show good agreement in their common overlap region. This comparison demonstrates directly how our in-cabin coarse SSA measurements are affected by the inlet passing efficiency relative to the ambient SSA from the GNI. It also indicates that our estimated effective $50 \%$ size cut of $2.16 \mu \mathrm{m}$ for dry SSA sizes may be closer to about $2.5 \mu \mathrm{m}$ and that SDI volume losses are about $50 \%$. 


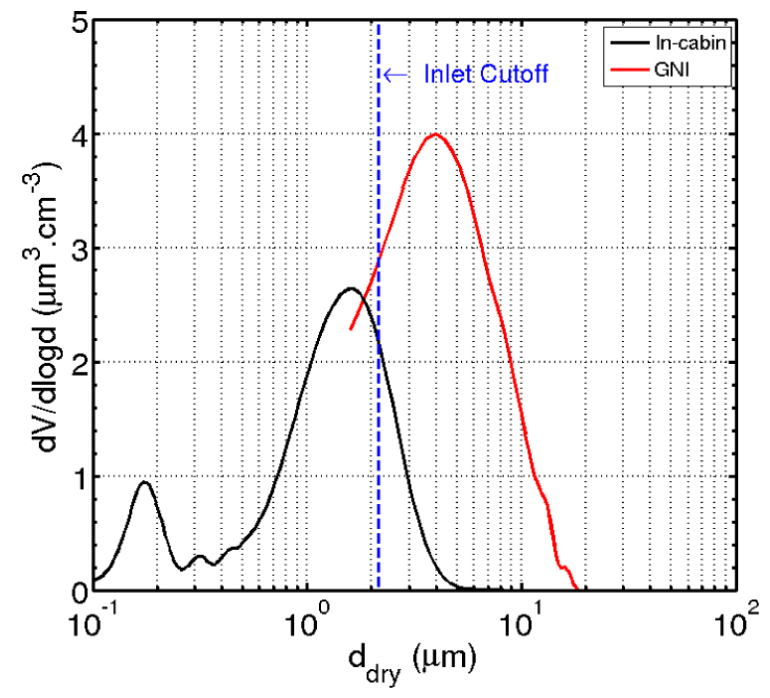

Fig. 2. Example of a clean MBL volume size distribution measured during VOCALS-REx (RF11, 18:27 UTC) for moderated wind speed $\left(11.5 \mathrm{~m} \mathrm{~s}^{-1}\right)$ and low altitude $(143 \mathrm{~m})$. Solid black and red lines represent measurements from the cabin instruments and from the GNI instrument, respectively. The blue vertical dashed line highlights the SDI $50 \%$ dry diameter cutoff. GNI sizing and counting uncertainty are both less than $10 \%$.

However, in this study we focus on number concentrations that are dominated by ultrafine sizes. McNaughton et al. (2007) studied the SDI performances in a marine environment during the DC-8 Inlet Characterization Experiment (DICE) where airborne and ground-based measurement inter-comparisons were performed. It was concluded that poor sampling for sizes above the $50 \%$ cutoff can lead to mass underestimates but these are generally a small fraction of the total number of particles. However, in spite of this SDI size limitation for SSA mass, also illustrated in Fig. 2 for VOCALS-REx, we will later show that this has a negligible influence on associated SSA number and CCN that are both dominated by sizes below this cutoff.

Large droplets encountered in cloud and during significant drizzle events can break-up within the inlet resulting in an unrealistic large number of ultrafine particles (Craig, 2012). These particulate artifacts are removed from the data used in this study.

\subsection{Particle counters}

Aerosol number concentrations were measured using two condensation nuclei $(\mathrm{CN})$ counters (Thermal Systems Inc., Model 3010). These instruments detect particles with a minimum size of $0.010 \mu \mathrm{m}$. One was operated at ambient cabin temperature while the other had its inlet heated at $360^{\circ} \mathrm{C}$ to infer aerosol volatile properties (Clarke, 1991). When heated over $300^{\circ} \mathrm{C}$, most mass associated with species like sulfuric acid and ammonium sulfate/bisulfate are removed (Clarke,
1991), whereas the non-volatile aerosol components such as $\mathrm{BC}$, dust and sea salt remain. The latter is the most common non-volatile component of SSA in most ocean regions, but other non-volatile components, stable at high temperatures and possibly transferred to the atmosphere by bursting bubbles, have been identified in the Arctic (Bigg and Leck, 2008). In this study, heated measurements are referred to as "non-volatile" data and ambient measurements represent the "total" amount of aerosol. The difference between ambient $\mathrm{CN}$ and heated $\mathrm{CN}$ provides the volatile aerosol number.

Full size distributions with diameters between $0.01 \mu \mathrm{m} \leq d \leq 10 \mu \mathrm{m}$ are obtained by combining a differential mobility analyser (DMA), a laser optical particle counter (OPC) and an aerodynamic particle sizer (APS). These instruments are briefly described below.

The DMA measured aerosol number size distributions with geometric diameters between 0.010 and $0.125 \mu \mathrm{m}$ (Zhou, 2001). It was operated along with a lagged aerosol grab (LAG) chamber described in Clarke et al. (1998) to store air for about 1 or 2 min while the DMA measures aerosol concentrations at ambient in-cabin temperature, 150 and at $300{ }^{\circ} \mathrm{C}\left(\mathrm{DMA}_{300}{ }^{\circ} \mathrm{C}\right)$.

The OPC (Particle Measurement Systems, Inc. LAS-X with custom electronics) sampled number size distributions for sizes between 0.125 and $0.5 \mu \mathrm{m}$. The OPC was operated with a dried $50: 50$ dilution flow to ensure that particles are measured "dry" at generally $30 \%$ RH. Measurements are strongly affected by Mie resonances (McMurry, 2000); for that reason, size distributions provided by the APS (see below) were preferred for sizes above $0.5 \mu \mathrm{m}$. A heating system adjusted the air temperature upstream of the OPC between 28.5 and $400^{\circ} \mathrm{C}$ (referred later as $\mathrm{OPC}_{400}{ }^{\circ} \mathrm{C}$ ) (Clarke, 1991) through a cycle of about $2 \mathrm{~min}$. The calibration was performed using polystyrene latex spheres (PSL) with a refractive index of 1.59 and glass beads with a refractive index of 1.54, which is suitable for SSA measurements (Shinozuka et al., 2004).

The APS model 3321 was used to measure aerosol concentrations with an aerodynamic diameter $\left(d_{\mathrm{a}}\right)$ between $0.5 \mu \mathrm{m}$ and $10 \mu \mathrm{m}$ every $15 \mathrm{~s}$. The APS is a time-of-flight (TOF) spectrometer that measures the velocity of particles in an accelerating air flow through a nozzle (Wilson and Liu, 1980). A calibration curve relating particle TOF to the $d_{\mathrm{a}}$ is provided using aerosols composed of monodisperse latex spheres with a refractive index of 1.59 and a density of $1.05 \mathrm{~g} \mathrm{~cm}^{-3}$. Older APS models are known to sometimes create "anomalous" large particles caused by recirculation within the detection region of the instruments (Peters and Leith, 2003, and references therein). On the model 3321 the particle processing circuitry and the outlet nozzle were redesigned to solve this issue. Particles are accelerated through the nozzle to produce a Reynolds number outside the Stokes regime. Assuming, for dry sea salt aerosol, a spherical shape and a density of $2.2 \mathrm{~g} \mathrm{~cm}^{-3}$, the Stokes correction proposed by Wang and John (1987) is applied to obtain the true $d_{\mathrm{a}}$. Then, $d_{\mathrm{a}}$ is 
converted into a geometric diameter using the same assumptions concerning particle shape, factor and density.

In addition to particle sizing, the aerosol scattering coefficient was measured using an integrating nephelometer (TSI, Model 3563) (Anderson et al., 1996) at $450 \mathrm{~nm}\left(\sigma_{450 \mathrm{~nm}}\right)$, $550 \mathrm{~nm}\left(\sigma_{550 \mathrm{~nm}}\right)$ and $700 \mathrm{~nm}\left(\sigma_{700 \mathrm{~nm}}\right)$ at $1 \mathrm{~Hz}$. The nephelometer detects light scattering over an angle range of $7-$ $170^{\circ}$ with a precision of $0.1 \mathrm{Mm}^{-1}$ for an averaged time of $30 \mathrm{~s}$.

Black carbon aerosol number and mass concentration emitted from combustion processes was sampled using a single particle soot photometer (SP2, Droplet Measurement Technologies). Particles passing through the instrument are excited by a $1064 \mathrm{~nm} \mathrm{Nd}$ : YAG intracavity laser. BC aerosols can be identified due to an incandescence temperature proper to these particles (Schwarz et al., 2006). A calibration curve relating the thermal radiation intensity measured by an incandescence detector and the $\mathrm{BC}$ mass was obtained using an aqueous suspension of Aquadag (Schwarz et al., 2006). Data from the same instrument were used in Shank et al. (2012). They found a minimum and a maximum particle size detection limit of 0.087 and $0.4 \mu \mathrm{m}$ assuming a BC density of $2 \mathrm{~g} \mathrm{~cm}^{-3}$. They also estimated a total uncertainty of $\pm 23 \%$ for the $\mathrm{BC}$ mass measurements.

Organics (Org) were measured with an Aerodyne highresolution time-of-flight mass spectrometer (AMS). The latter uses an aerodynamic lens assembly to focus $0.035-1 \mu \mathrm{m}$ vacuum aerodynamic diameter particles but is mostly accurate for aerosols in the size range of about 0.05-0.6 $\mu \mathrm{m}$. Details concerning the AMS during VOCALS-REx are also described in Shank et al. (2012). The detection limit decreased after several hours of sampling from $0.02 \mu \mathrm{g} \mathrm{m}^{-3}$ for one minute total data at the beginning of a flight to $0.014 \mu \mathrm{g} \mathrm{m}^{-3}$ for $6.5 \mathrm{~h}$ after take-off.

\subsection{Meteorological data}

The three components of wind velocity were calculated measuring pressure differences in the $\mathrm{C}-130$ gust radome probe and using an inertial reference system (IRS). Horizontal wind speed measurements provided by the probe are accurate to better than $1 \mathrm{~m} \mathrm{~s}^{-1}$. Intercomparison flights report the same order of uncertainty (Allen et al., 2011).

The precipitation rate was calculated using the raindrop total volume measured with the Particle Measuring Systems two-dimensional cloud probe (2D-C, PMS Inc.) mounted on the $\mathrm{C}-130$ wing. The $2 \mathrm{D}-\mathrm{C}$ measures drop size distributions in the range of $25-800 \mu \mathrm{m}$. These measurements acquired for in-cloud and sub-cloud legs combined with the radius-dependent terminal velocity found in Rogers (1979) and based on the Gunn and Kinzer (1949) dataset provide the estimate of the precipitation for our study.

Cloud-top and base altitude were measured with the Wyoming Cloud Lidar (WCL) (Wang et al., 2009). Height of the inversion is approximated by the cloud top height.

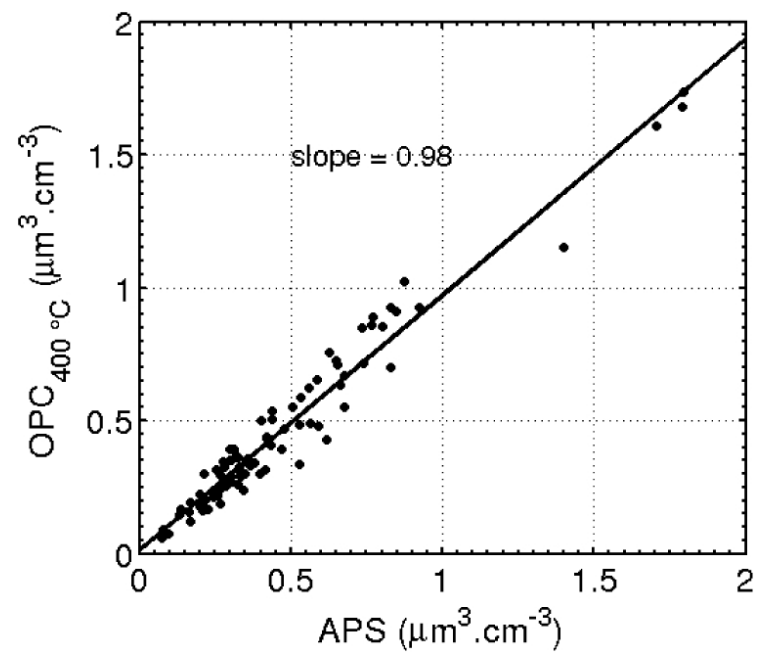

Fig. 3. Comparison between $\mathrm{OPC}_{400}{ }^{\circ} \mathrm{C}$ and APS volume concentrations for $0.8 \mu \mathrm{m} \leq d_{\mathrm{dry}} \leq 1.5 \mu \mathrm{m}$ in the MBL during VOCALSREx. Each point represents data averaged over $10 \mathrm{~min}$. The slope of the regression is shown.

\section{5 "Dry" diameter}

To avoid influences of relative humidity on marine aerosol sizes and their optical properties, all in-cabin measurements are operated "dry". SSA concentrations are sampled well under the efflorescence point for sea salt aerosols around $45-48 \%$. For heated instruments, we assume that the residence time in each heater is long enough for the particles to dry completely. The nephelometer and the APS are not heated, but the pressure increases along the inlet line bring the air at RH lower than $35 \%$ inside the instruments even in a humid MBL. However, even for very low RH, we recognize that some uncertainty still remains regarding the residual amount of water associated with sea salt particles (Tang et al., 1997). Figure 3 compares total volume concentrations for particle sizes between $0.8 \mu \mathrm{m} \leq d \leq 1.5 \mu \mathrm{m}$ measured in the MBL with the $\mathrm{OPC}_{400}{ }^{\circ} \mathrm{C}$ with the APS during VOCALSREx. This size range is used because the OPC is less affected by Mie resonance here and it agrees the best with the APS. It can be seen that the slope of the regression between volume concentrations measured with the two instruments differ less than $2 \%$ from the $1: 1$ line. This shows that the drying effect due to pressure changes in the sample line is effective and that the water contribution to particle volume should be negligible in the APS and the nephelometer. Therefore, in this study we always refer to the aerosol diameter as $d_{\text {dry }}$, the diameter of the particle in a solid state. 

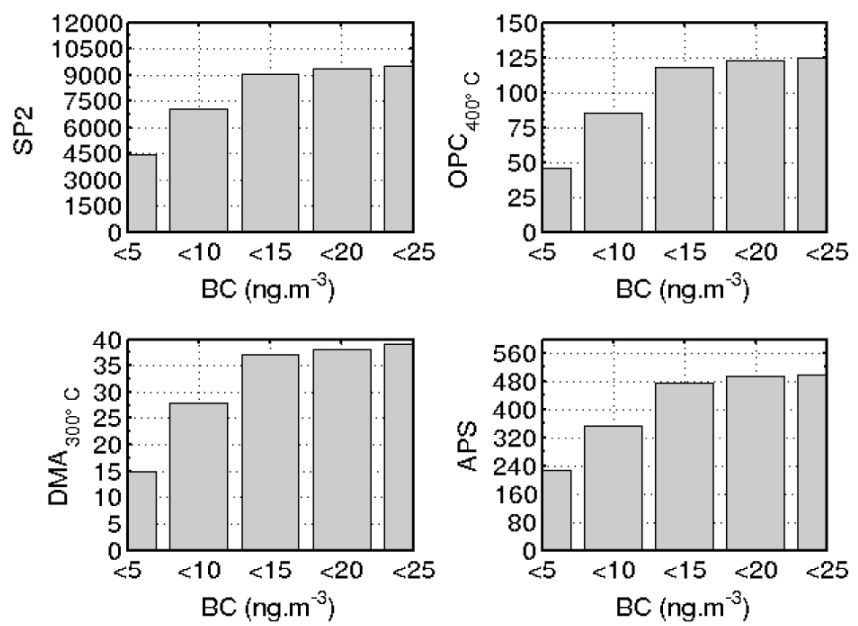

Fig. 4. Total number of data points per instrument stratified by BC concentration for altitudes below $200 \mathrm{~m}$.

\section{Method}

\subsection{Data stratification}

To access the total number of SSAs and especially to identify the smallest sizes, it is essential to work with clean cases and avoid contamination of the measurements either by longrange pollution transport or local pollution from South America. BC detected with the SP2 is an excellent indicator for combustion aerosols and low but measurable amounts were found even in the cleanest air during VOCALS-REx (Shank et al., 2012). Therefore, the challenge is to find a threshold for pollution which would ensure that our SSA number size distributions are insignificantly affected by anthropogenic aerosols. Here we describe the tools used to identify size distributions most representative of "clean". It consists in constraining all the data for BC, Ångström coefficients and organics at values intended to ensure low pollution. However, these thresholds should be high enough to provide a database that is also statistically significant.

Figure 4 illustrates the total number of VOCALS-REx size distributions per instrument stratified by BC. It shows that at altitude lower than $200 \mathrm{~m}$ most $\mathrm{BC}$ concentrations are below $25 \mathrm{ng} \mathrm{m}^{-3}$, and that the number of full size distributions available for statistical analysis is constrained by $\mathrm{DMA}_{300}{ }^{\circ} \mathrm{C}$. This is due to the time needed to complete the three temperature cycles used for volatility assessments. Only one or two DMA thermal scan cycles are completed during one surface leg, while acquisition of size distributions by the other instruments is faster. Since ultrafine SSA measured by $\mathrm{DMA}_{300^{\circ} \mathrm{C}}$ is the special interest of this study, a lower value for BC will probably be in the range of $15-25 \mathrm{ng} \mathrm{m}^{-3}$. Note that this range corresponds to $\mathrm{BC}$ number concentrations less than 5$9 \mathrm{~cm}^{-3}$ and should not contribute significantly to the total number of aerosol.

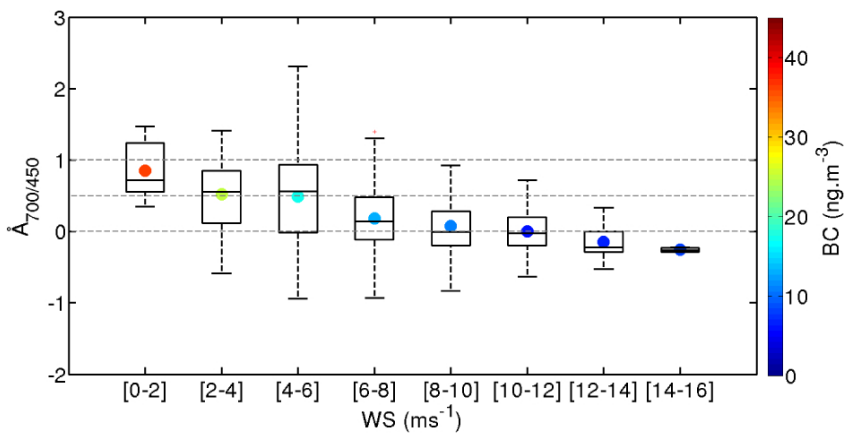

(a)

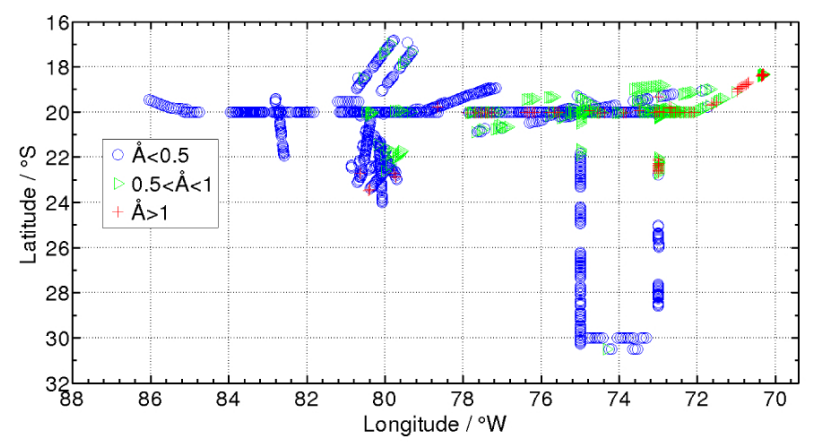

(b)

Fig. 5. (a) ̊̊ngström exponent $(\AA)$ box plot binned per WS intervals for altitudes below $200 \mathrm{~m}$. Dots represent the mean value color-coded with BC concentration. (b) Ångström exponent spatial distribution over the VOCALS-REx region for 3 bins. Each symbol represents data averaged over $60 \mathrm{~s}$. For both plots the Ångström exponents are calculated using $\sigma_{450 \mathrm{~nm}}$ and $\sigma_{700 \mathrm{~nm}}$.

The wavelength dependence of light scattering is defined by the Ångström exponent ( $\AA$ ) (Ångström, 1929) and provides rapid information related to the size distributions. Values near zero occur when scattering is dominated by coarse aerosols (e.g., sea salt) and values around two are dominated by submicrometer sizes in the accumulation mode (e.g., combustion pollution) with intermediate values indicating a mix of sizes. Generally, $\AA$ is inversely related to the effective size of aerosols (Schuster et al., 2006). In the absence of removal processes, higher surface wind speed (WS) leads to smaller $\AA$ since WS is well known for being the key meteorological parameter linked to the production of coarse sea salts at the sea surface (Lewis and Schwartz, 2004). A value close to zero does not guaranty that pollution is absent, but it suggests that size distributions are dominated by SSA and are more representative of a cleaner maritime air mass (Clarke and Kapustin, 2003; Vaishya et al., 2011). As expected, Fig. 5a shows that $\AA$ typically decreases as WS increases in the MBL over the SEP. It also reveals that when WSs are high enough to induce significant whitecaps (above $5-6 \mathrm{~m} \mathrm{~s}^{-1}$ ), most $\stackrel{\AA}{\mathrm{s}}$ are below 0.5 and can even take negative values at WSs larger 
than $10 \mathrm{~ms}^{-1}$. These negative $\AA$ imply that concentrations increase with the larger SSAs that scatter visible light more strongly (Bodhaine and Deluisi, 1985).

Figure 5 b illustrates how $\AA$ varies over the SEP in the MBL. It can be seen that values lower than 0.5 are located farther offshore and in the southern region while the majority of $\AA$ higher than 0.5 are observed close to the coast along $20^{\circ} \mathrm{S}$. MBL back trajectories using the National Center for Environmental Prediction reanalysis (Allen et al., 2011; Bretherton et al., 2010) showed that the majority of the air masses along $20^{\circ} \mathrm{S}$ come from the south. However, east of $75^{\circ} \mathrm{W}$ most the trajectories pass over the Chilean coast, where they are influenced by local pollution, while west of $75^{\circ} \mathrm{W}$ MBL back trajectories stay away from the coast by distances of several hundred kilometers, keeping a strong marine signature. These explain why $\mathrm{BC}$ concentrations are higher for larger $\AA$ as it is observed in Fig. 5a. Therefore, we can concluded that $\AA$ higher than 0.5 are influenced by pollution.

Based on these findings, we have decided to select measurements with $\AA$ lower than 0.5 , corresponding to mean $\mathrm{BC}$ concentrations below $15 \mathrm{ng} \mathrm{m}^{-3}$ (Fig. 5a), as a criterion for clean air where we should be able to identify measurements representative of a clean marine environment. Anthropogenic submicrometer organic aerosols may also affect our SSA total number estimation. Shank et al. (2012) showed that over the SEP, even at very low pollution levels, combustion sources dominated the organics. Therefore, data with organic concentrations above AMS detection limits $\left(0.02 \mu \mathrm{g} \mathrm{m}^{-3}\right)$ have been excluded.

\subsection{Clean size distribution and potential CCN}

Figure 6a shows an example of total and non-volatile number size distributions at $150 \mathrm{~m}$ altitude in the MBL for moderate WS $\left(7.5 \mathrm{~m} \mathrm{~s}^{-1}\right)$, very low BC $\left(1.6 \mathrm{ng} \mathrm{m}^{-3}\right)$ and $\AA(0)$ measured over the SEP during VOCALS-REx. Note that these values are well below the clean thresholds established above. The total number size distribution (unheated) shown in Fig. 6a reveals a minimum of concentration located between 0.05 and $0.08 \mu \mathrm{m}$. This so-called Hoppel minimum is common in the MBL due to the growth of particles processed in clouds over oceans (Hoppel et al., 1986). Gas-toparticle conversion and aqueous phase chemistry processes add mass preferentially to activated aerosols compared to unactivated interstitial aerosols. Upon cloud evaporation, these activated aerosols have grown larger and, over time, this results in a minimum near $0.08 \mu \mathrm{m}$ forming at dry sizes. Natural volatile sulfate species and SSAs with diameters above this minimum and under weak supersaturation can directly act as CCN.

Cloud supersaturation is not directly measurable, but the center of the Hoppel minimum indicates the influence of the most common or frequent supersaturation present in the ambient clouds. The width of the Hoppel minimum (range of di-
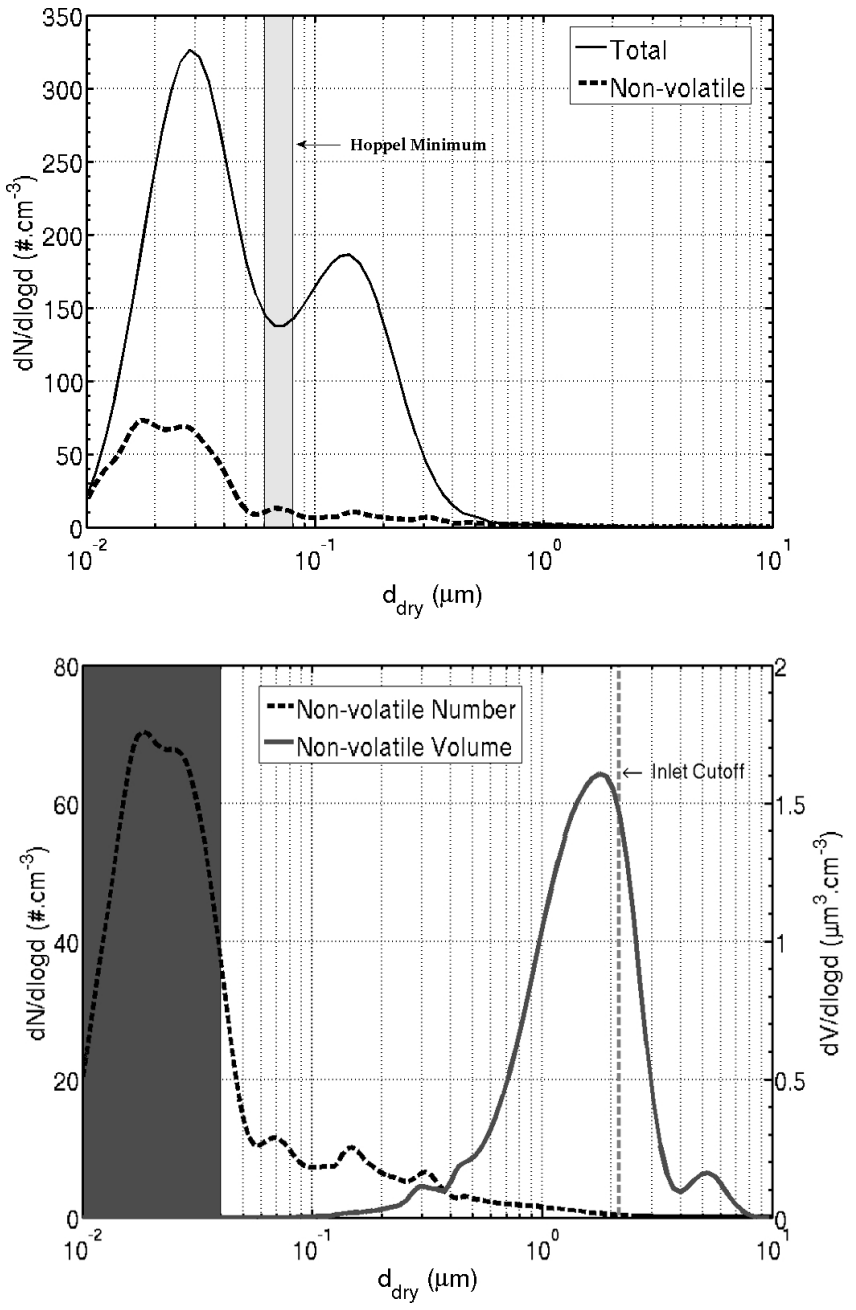

Fig. 6. (a) Example of averaged total and non-volatile clean size distributions measured for $\mathrm{WS}=7.5 \mathrm{~ms}^{-1}, \AA=0, \mathrm{BC}=1.6 \mathrm{ng} \mathrm{m}^{-3}$ and altitude $=150 \mathrm{~m}$. (b) Same plot with only the non-volatile number and its volume size distribution. The vertical dashed line indicates the inlet cutoff diameter. The shaded area corresponds to the non-volatile sizes excluded from our analysis.

ameters) also provides a measure of the range of supersaturation active in the clouds. Therefore, the Hoppel minimum can be used to estimate the mean MBL cloud supersaturation but on a cloud scale there can be significant variability. In fact, stratocumulus clouds include air parcels with a continuum of different updraft and supersaturation histories (Snider et al., 2003). Particles smaller than the Hoppel minimum can be activated in strong updrafts (i.e., higher supersaturations); they just have not been through enough condensation/evaporation cycles to grow through the gap.

The relationship between the critical supersaturation and the minimum dry size at which particles activate can be derived from Köhler theory (Köhler, 1936). A simple expression for ammonium sulfate aerosols can be found in 
Hoppel et al. (1996):

$\mathrm{SS}_{\text {critical }}(\%)=\left[K\left(\frac{d_{\mathrm{dry}_{\min }}}{2} \times 10^{-4}\right)^{-3 / 2}\right] \times 100$

where $K=1.71 \times 10^{-11} \mathrm{~cm}^{3 / 2}$ and $d_{\mathrm{dry}_{\min }}$ in $\mu \mathrm{m}$. We can use Eq. (1) to deduce the range of supersaturation associated with the very clean size distribution presented in Fig. 6. Assuming that the total number is largely dominated by ammonium sulfate aerosols (Clarke, 1991) and that the Hoppel minimum shown by the narrow grey line $\left(0.05 \mu \mathrm{m} \leq d_{\mathrm{dry}_{\min }} \leq 0.08 \mu \mathrm{m}\right)$ is representative of most typical supersaturation values in clouds, we can estimate that these are in the range of 0.20$0.30 \%$. It can be noted that these supersaturations obtained for a VOCALS-REx total number size distribution are very similar to Hoppel et al. (1996) for non-precipitating clouds over the Atlantic Ocean. However, the shape of the minimum (when compared to an original monomodal distribution) is extended down to much smaller sizes. These would have to be calculated by fits to the original distributions (which we do not have here), but we note that a significant fraction of sizes down to about $0.035 \mu \mathrm{m}$ were also activated.

Mean ambient supersaturations in VOCALS-REx clouds, when estimated from the Hoppel minimum in the size distributions, provides a way to estimate the SSA CCN number. SSA is known to be highly CCN active and was shown to grow similarly to pure sodium chloride particles (Bates et al., 2012; Niedermeier et al., 2008), independently of the exact SSA chemical composition. Niedermeier et al. (2008) performed measurements and calculations of SSA activation using different water samples. They proposed the following relationship between supersaturation and the particle dry diameter (at RH $>95 \%$ ) which we will use here for SSA instead of Eq. (1):

$\mathrm{SS}(\%)=\left[\frac{6.32 \times 10^{-7}}{T} \frac{1}{d_{\mathrm{wet}}}-0.98 \frac{d_{\mathrm{dry}}^{3}}{d_{\mathrm{wet}}^{3}-d_{\mathrm{dry}}^{3}}\right] \times 100$

where $T$ is the temperature in Kelvin, $d_{\text {wet }}$ is the droplet diameter in meters and $d_{\text {dry }}$ the SSA dry size also in meters. Assuming a standard critical supersaturation of $0.25 \%$ deduced from the Hoppel minimum of a very clean total size distribution (Fig. 6a) for stratocumulus clouds over the SEP, we can calculate from Eq. (2), via Newton approximation, that only the SSAs larger than $0.060 \mu \mathrm{m}$ can act as CCN.

Figure $6 \mathrm{~b}$ shows a vertical exaggeration of the clean nonvolatile number size distribution. Since pollution indicators are well below the thresholds established above and the volatile fraction mostly composed of sulfates from DMS (Clarke, 1991), we argue that the size distribution shown here is representative of clean SSA over the SEP and can be integrated to estimate SSA CCN number. However, we exclude from our interpretation sizes lower than $0.040 \mu \mathrm{m}$ (shaded area) for two reasons. First, some larger sulfate species may not be completely volatilized. Even if they lose $99 \%$ of their mass, a small residual can remain at the lowest size detected by the $\mathrm{DMA}_{300}{ }^{\circ} \mathrm{C}$. Secondly, the AMS does not detect organic aerosols smaller than $0.035 \mu \mathrm{m}$. Although the APS measuring coarse aerosols did not assess volatility, because of the lack of volatility in the larger sizes detected by the OPC in clean air during VOCALS-REx, all particles larger than $0.8 \mu \mathrm{m}$ are assumed to be SSAs (see also Murphy et al., 1998). However, as shown with the volume size distribution plotted in Fig. 6b, coarse SSAs (sea salt) dominate total volume (mass) but their contribution to number is negligible.

Finally, on this particular example for moderate WS and minimal pollution (Fig. 6) and for a $0.25 \%$ supersaturation, we can deduce that SSAs larger than $0.060 \mu \mathrm{m}$ active as CCN would account for $7 \%$ of the total number $(37 \%$ for surface area and $80 \%$ for volume) of aerosol particles sampled through the inlet.

\subsection{Identifying ultrafine SSAs}

Here we demonstrate that our MBL non-volatile number concentrations for sizes larger than $0.040 \mu \mathrm{m}$ are part of the SSA distribution. We constrain all the MBL VOCALS-REx data using the clean case thresholds described earlier for $\AA$, BC and Org concentrations in order to isolate the SSA contribution to the total number of aerosol.

Light scattering at $700 \mathrm{~nm}$ is well known to be most sensitive to the larger aerosol sizes (Murphy et al., 1998). Figure $7 \mathrm{a}$ shows that the scattering coefficient in a clean MBL is very well correlated $\left(R^{2}=0.97\right)$ with coarse sea salt numbers measured with the APS, and the intercept of the linear regression approaches zero indicating that the lowest scattering at this wavelength corresponds to negligible coarse SSA concentrations. Figure $7 \mathrm{~b}$ presents MBL total aerosol number measured with the $\mathrm{DMA}_{300}{ }^{\circ} \mathrm{C}$ for dry diameters between $0.040 \mu \mathrm{m}$ and $0.125 \mu \mathrm{m}$. The correlation coefficient $\left(R^{2}=0.87\right)$ shows that variations in non-volatile submicrometer aerosol number down to $0.040 \mu \mathrm{m}$ are also well correlated with scattering at $700 \mathrm{~nm}$ and thus with coarse SSA concentration. Note that this correlation coefficient be-

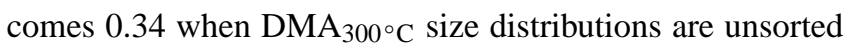
for pollution. Hence, by constraining measurements to the cleanest conditions, we demonstrate here that concentrations for sizes between 0.040 and $0.125 \mu \mathrm{m}$ vary with the larger sizes that dominate the light scattering and are known to be SSAs. Therefore, we argue that these ultrafine sizes are part of the SSA population. We note that this is consistent with Twohy et al. (2013), who collected sea salt particles as small as $0.050 \mu \mathrm{m}$ with a micro-impactor for very clean air during VOCALS-REx. The latter samples were analyzed by transmission electron microscope (TEM).

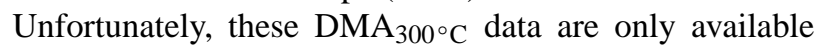
for limited time periods and are further constrained for clean conditions. In order to increase the amount of available data representative of these ultrafine sizes, we demonstrate that these $\mathrm{DMA}_{300^{\circ} \mathrm{C}}$ data are linearly related to 


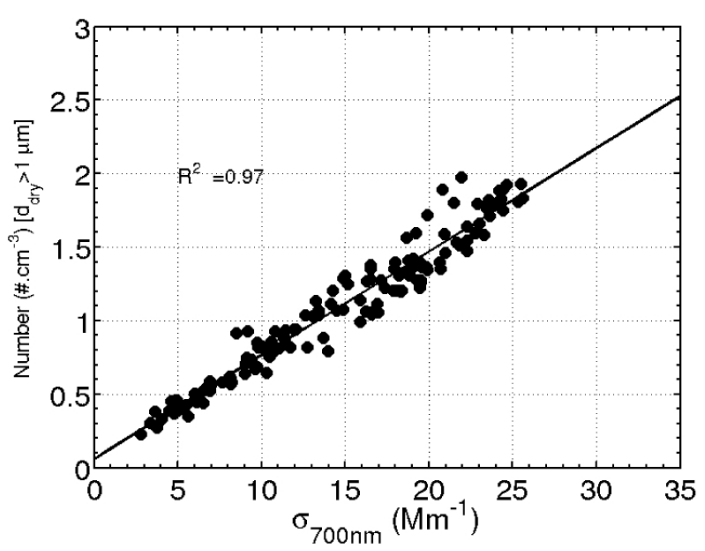

(a)

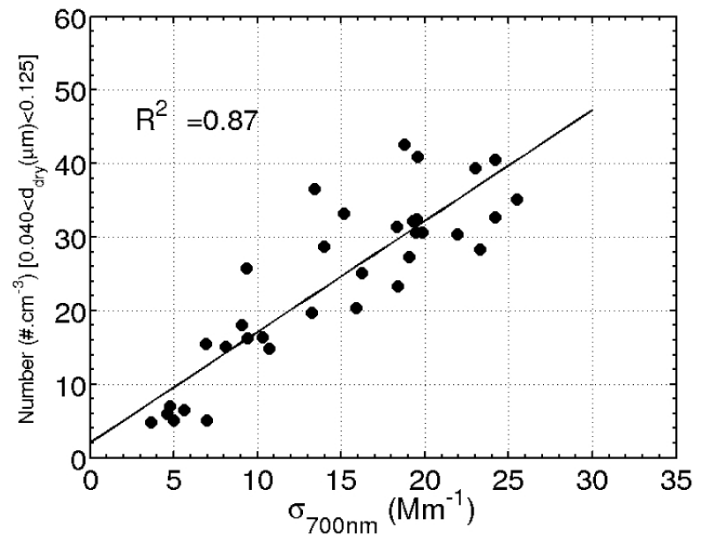

(b)

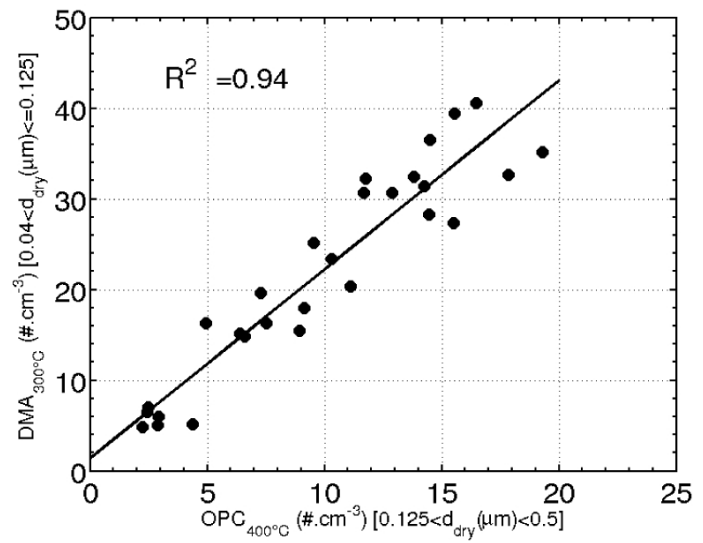

(c)

Fig. 7. (a) Comparison between $\sigma_{700 \mathrm{~nm}}$ and total aerosol number larger than $1 \mu \mathrm{m}$ using the APS for clean cases in the MBL. (b) Same with $\mathrm{DMA}_{300}{ }^{\circ} \mathrm{C}$ for $0.040 \mu \mathrm{m} \leq d_{\text {dry }}<0.125 \mu \mathrm{m}$. (c) Total aerosol number provided by $\mathrm{DMA}_{300}{ }^{\circ} \mathrm{C}$ for $0.040 \mu \mathrm{m} \leq d_{\text {dry }}<0.125 \mu \mathrm{m}$ and total aerosol number using $\mathrm{OPC}_{400}{ }^{\circ} \mathrm{C}$ with $0.125 \mu \mathrm{m} \leq d_{\text {dry }} \leq 0.5 \mu \mathrm{m}$ for VOCALS-REx clean air cases.
$\mathrm{OPC}_{400}{ }^{\circ} \mathrm{C}$ measurements, which have 3 times more data For that, we first test whether these measurements reflect the same population. Figure $7 \mathrm{c}$ presents a comparison between the non-volatile aerosols measured with $\mathrm{DMA}_{300}{ }^{\circ} \mathrm{C}$ and $\mathrm{OPC}_{400}{ }^{\circ} \mathrm{C}$ for $0.040 \mu \mathrm{m} \leq d_{\text {dry }}<0.125 \mu \mathrm{m}$ and $0.125 \mu \mathrm{m} \leq d_{\mathrm{dry}} \leq 0.5 \mu \mathrm{m}$, respectively. The correlation coefficient $\left(R^{2}=0.94\right)$ indicates that size distributions based on these size ranges vary similarly in response to aerosol number variations. Hence, taking this linear relationship for a minimum dry diameter of $0.040 \mu \mathrm{m}$, SSA number concentration can be inferred from the more frequent $\mathrm{OPC}_{400}{ }^{\circ} \mathrm{C}$ measurements available under clean conditions. We note that this conclusion is also true for SSAs active as CCN with dry diameter larger than $0.060 \mu \mathrm{m}$.

\subsection{Comparing open-ocean and coastal breaking- wave SSAs}

These open-ocean non-volatile SSAs constrained for the cleanest conditions during VOCALS-REx are compared here to non-volatile SSA number concentrations produced unambiguously by individual coastal breaking waves (Clarke et al., 2006). During the SEAS (Shoreline Environment Aerosol Study) experiment, a coastal tower on Oahu, Hawaii (Clarke and Kapustin, 2003), was used to sequentially sample aerosols at three altitudes in order to isolate the influence of particles produced by bubble-bursting from coastal breaking waves (bottom of tower) from the ambient background (top of tower). Data clearly showed the excursion in ambient light scattering and non-volatile $\mathrm{CN}\left(d_{\mathrm{dry}} \geq 0.01 \mu \mathrm{m}\right)$ of fresh SSA on a wave-by-wave basis (Fig. 3 in their study) resulting in a strong linear relationship $\left(R^{2}=0.95\right)$ between total non-volatile number and light scattering at $550 \mathrm{~nm}$. Since the same kind of relationship is observed for VOCALS-REx, it is pertinent to compare these two datasets obtained from distinct environments.

Data from SEAS need to be rescaled for comparison with our VOCALS-REx non-volatile SSAs because of two reasons. First, as mentioned earlier (Sect. 3.2), the SDI inlet efficiency has a small impact on SSA number but some of the coarse particle contribution to light scattering is lost. During SEAS larger particles were sampled more effectively compared to VOCALS-REx. Secondly, SEAS aerosol number included SSAs with $d_{\text {dry }}$ larger than $0.01 \mu \mathrm{m}$, while our VOCALS-REx measurements are given here for diameters larger than $0.040 \mu \mathrm{m}$ (see also Sect. 3.2). Hence, we describe below how original SEAS data are rescaled to fit our instrumental limitations.

Figure 8 shows an example of scattering coefficients per dry diameter bin width calculated from a number size distribution from SEAS. The ground-based SEAS inlet passed coarse aerosol up to $8 \mu \mathrm{m}$ while for VOCALS-REx the dry cutoff is at about $2.16 \mu \mathrm{m}$ (see Sect. 2.2). Figure $8 \mathrm{~b}$ shows that about $50 \%$ of the scattering for SEAS is derived from dry sizes larger than $2.16 \mu \mathrm{m}$. Hence, SEAS 


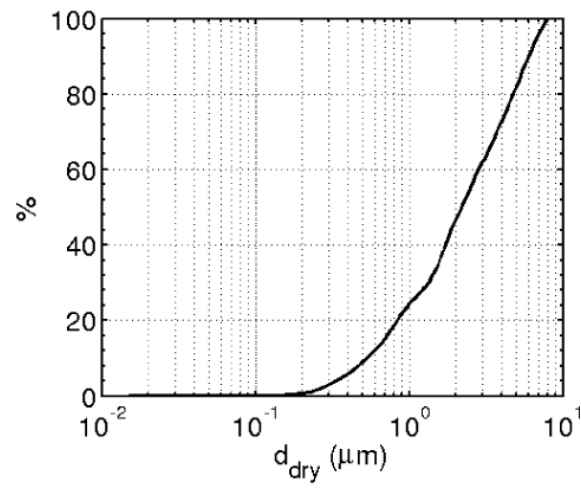

(a) $\sigma_{550 \mathrm{~nm}}$ size distribution

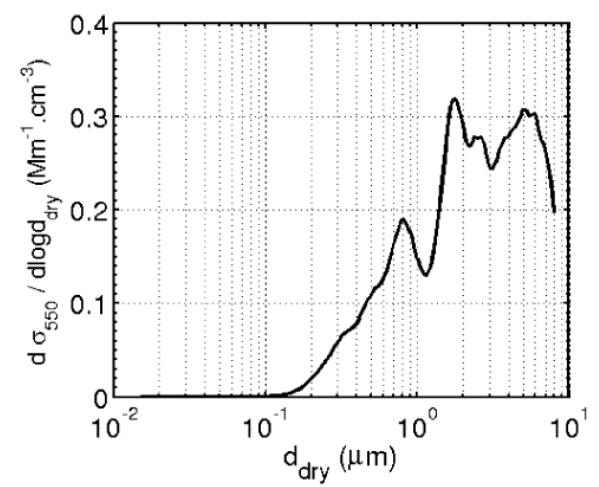

(b) Cumulative distribution

Fig. 8. (a) Example of scattering size distribution derived from a number size distribution measured during SEAS. (b) Normalized cumulative distribution of scattering coefficients associated with (a).

scattering coefficients need to be divided by a factor of two in order to be compared with VOCALS-REx data. For numbers, the mean SEAS non-volatile SSA number size distribution (Clarke et al., 2006; Fig. 1) shows that the fraction of SSAs larger than $0.040 \mu \mathrm{m}$ and $0.060 \mu \mathrm{m}$ represented 70 and $35 \%$ of the total spectra with a minimum diameter of $0.01 \mu \mathrm{m}$. Therefore, the SEAS SSA numbers presented below are rescaled to fit the minimum sizes used in this study.

These relationships between SSA non-volatile number and scattering at $550 \mathrm{~nm}$ for dry diameters larger than 0.040 and $0.060 \mu \mathrm{m}$ are illustrated in Fig. 9a, b for VOCALS-REx (black) and SEAS rescaled (red). Both subfigures show that clean SSA number concentrations measured directly from individual breaking waves and from our carefully stratified data for a clean open-ocean environment are very similar and their linear dependencies (slope) with scattering differ less than $10 \%$ for sizes larger than $0.040 \mu \mathrm{m}$ and for $\mathrm{CCN}$ active sizes larger than $0.060 \mu \mathrm{m}$.

Consequently, these findings show that the fundamental relationship between light scattering and ultrafine SSA established for SEAS is also evident for the open ocean and the similarity in number concentrations between the two datasets confirms that the SSA source function (Clarke et al., 2006) developed from coastal SEAS data remains applicable to the VOCALS-REx open-ocean environment.

\section{SSA variability during VOCALS-REx}

In the previous sections, we described an approach to establish total number of SSAs for sizes larger than $0.040 \mu \mathrm{m}$ through integrating our C-130 non-volatile size distribution measurements for clean MBL cases. Here, we use these results to study the MBL SSA concentration variability along $20^{\circ} \mathrm{S}$.

\subsection{Number concentrations along $20^{\circ} \mathrm{S}$}

The study of the aerosol concentrations can only be interpreted in the context of processes responsible for influencing their variability. For a given SSA source strength (e.g., surface flux expected to be primarily driven by WS), the resulting ambient SSA concentrations are influenced by fetch, boundary layer depth, MBL mixing processes including cloud processes, entrainment of air from the FT, removal by precipitation, dry sedimentation and coagulation processes (Lewis and Schwartz, 2004). Unfortunately, most of these processes are not easily measurable, and they exert a variable influence depending upon meteorology within the air mass history. However, during VOCALS-REx 4 research flights were fully dedicated to $20^{\circ} \mathrm{S}$ and 5 others combined $20^{\circ} \mathrm{S}$ and the POCs drifted study. Hence, these allow a statistical characterization of directly measurable parameters which are expected to have quantifiable impact on SSA concentrations. For these reasons, in this study we focus on in situ wind speeds (SSA production), cloud thickness (linked to cloud processing), inversion height (influences the total aerosol column) and precipitation (a dominant removal term) acquired on the $\mathrm{C}-130$. We note that data measured in POCs intercepting the $20^{\circ} \mathrm{S}$ parallel were removed. Enhanced drizzle has been shown to occur in POCs (Wood et al., 2011a) and would interfere with our $20^{\circ} \mathrm{S}$ study.

The mean wind field over the SEP can also be obtained from reanalysis data. Figure 10a shows ECMWF reanalysis surface WS averaged over the time of the VOCALS-REx period. It reveals the influence of the southeast Pacific anticyclone which produces predominantly southerly winds near $20^{\circ} \mathrm{S}$ at low levels that remain southerly close to the coast of Chile but exhibit increased divergence and turn into southeast trades farther offshore (more details in Garreaud and Muñoz, 2005). The resulting measured WS along $20^{\circ} \mathrm{S}$ is shown in Fig. 10b. There is a well defined zonal gradient of WS from $5 \mathrm{~m} \mathrm{~s}^{-1}$ close to the coast to $10.5 \mathrm{~m} \mathrm{~s}^{-1}$ over the open ocean. 


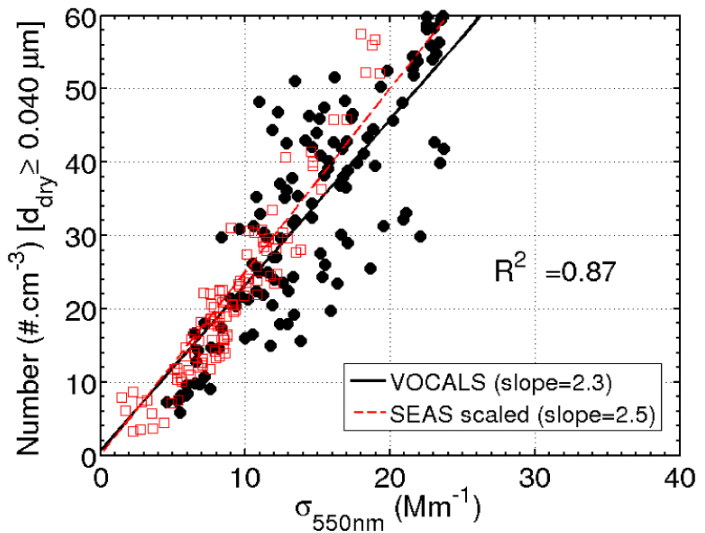

(a) $d_{d r y} \geq 0.040 \mu \mathrm{m}$.

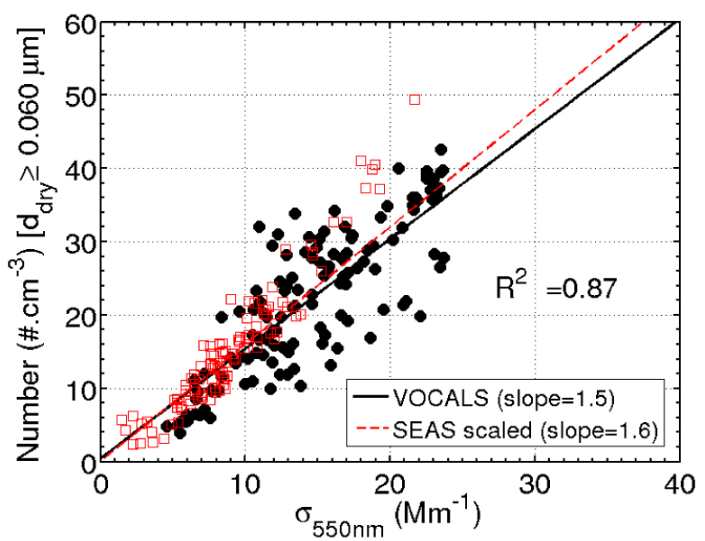

(b) $d_{d r y} \geq 0.060 \mu \mathrm{m}$.

Fig. 9. Clean MBL non-volatile aerosol number compared with the MBL $\sigma_{550 \mathrm{~nm}}$. Size distributions are integrated for (a) $d_{\text {dry }} \geq 0.040 \mu \mathrm{m}$ and for (b) $d_{\text {dry }} \geq 0.060 \mu \mathrm{m}$. Black dots are VOCALS-REx measurements and red squares are SEAS data scaled for VOCALS-REx minimum $d_{\mathrm{dry}}$ and inlet efficiency. The dashed lines represent the linear regressions for both datasets. Correlation coefficients are given only for VOCALS-REx data.

In the ideal case of no removal over the SEP, the MBL SSA concentrations along $20^{\circ} \mathrm{S}$ would be the result of local production of particles during transport from the southern region (see Fig. 10a) when wind speeds are high enough to induce breaking waves. As increasing WS to the west along $20^{\circ} \mathrm{S}$ (Fig. 10b) share similar trajectories in the MBL, we can ask first what trends might be expected for the SSA concentration variations.

Hence, we consider here a simple estimate (see Appendix for details) for the trend in build-up of MBL SSA along $20^{\circ} \mathrm{S}$. We assume that without precipitation it would take roughly $48 \mathrm{~h}$ (Yang et al., 2012) for an initial clean air mass entrained south of $30^{\circ} \mathrm{S}$ to reach $20^{\circ} \mathrm{S}$ at an averaged wind speed of $10 \mathrm{~m} \mathrm{~s}^{-1}$. We also assume that wind speeds are constant at their mean value measured along $20^{\circ} \mathrm{S}$ for each interval of longitude. Finally, we model SSAs larger than $0.060 \mu \mathrm{m}$ that can be activated at a standard supersaturation of $0.25 \%$ (see Sect. 3.2). The resulting SSA concentrations are shown in Fig. 11 (black circles). As expected, modeled SSA increases monotonically in response to the increase of WS along $20^{\circ} \mathrm{S}$. Given our simplistic assumptions, we do not argue that these values are valid, but we do argue that the trend in concentrations is what should be reasonable if production due to increasing wind were the determining factor.

However, this model trend is clearly inconsistent with the observed trend in measured SSA concentrations also shown in Fig. 11 (red squares). Although WS increases steadily west of $78^{\circ} \mathrm{W}$, a related increase in SSA concentrations is not evident. Concentrations appear to follow the trend in WS between the longitude $75^{\circ} \mathrm{W}$ and the longitude $81^{\circ} \mathrm{W}$. These are fairly constant at about $30 \mathrm{~cm}^{-3}$ followed with an increase to $36 \mathrm{~cm}^{-3}$, but west of $81^{\circ} \mathrm{W}$ the concentrations decrease, down to $17 \mathrm{~cm}^{-3}$ at $86^{\circ} \mathrm{W}$. This may imply a strong dilution offshore caused by changing inversion heights or/and an active sink term that is not in the model.

The variation of the inversion height, taken as equal to the cloud top height, is presented in Fig. 9c as a function of longitude along $20^{\circ} \mathrm{S}$. The observed increase to the west should be accompanied by entrainment of air low in SSAs leading to a dilution of MBL SSA concentrations. Hence, a first order correction obtained by normalizing SSA concentrations for a constant inversion height is also plotted in Fig. 11. It can be seen that resulting values are higher than those measured, but still decrease west of $81^{\circ} \mathrm{W}$. Therefore, dilution processes can not explain the decrease observed offshore.

Figure 10 also shows cloud thickness (Fig. 10c) and precipitation (Fig. 10d). It reveals that precipitation rate is markedly higher to the west in the more pristine region with deeper clouds (Bretherton et al., 2010) and that the marked increase in precipitation rate (Fig. 10d) occurs in the region of greatest disagreement between measured and model SSA concentrations (Fig. 11). Hence, we argue that the increase in precipitation of about $1 \mathrm{mmd}^{-1}$ (Fig. 10d) overwhelms the SSA production associated with the increase in WS (Fig. 10b). This suggests that precipitation via coalescence scavenging (Mechem et al., 2006; Wood, 2006) is a primary sink of SSA offshore over the SEP. Wood et al. (2012) showed that precipitation increase along $20^{\circ} \mathrm{S}$ can explain by itself the $\mathrm{CCN}$ depletion observed offshore over the VOCALS-REx region (Allen et al., 2011). They estimated that west of $80^{\circ} \mathrm{W} \mathrm{CCN}$ concentrations would be larger by at least a factor of 2 if precipitation did not occur in this region. Consequently, the difference between our observed and model SSA trends west of $80^{\circ} \mathrm{W}$ would be much less if wet removal was properly taken into account.

Along with number concentrations the mass mixing ratio of SSA to dry air at $20^{\circ} \mathrm{C}$ is presented in Fig. 11. In order to account for losses of larger particles in the SDI, we have applied the previously discussed factor of 2 , deduced from 


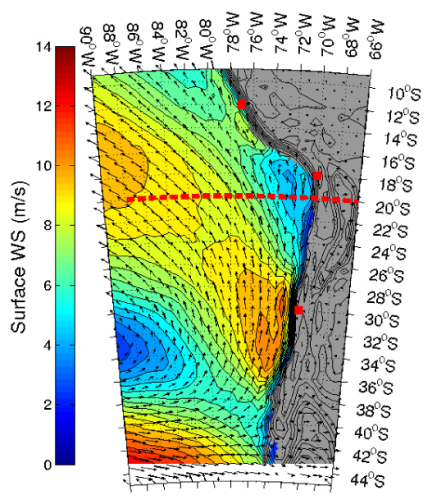

(a) WS from ECMWF

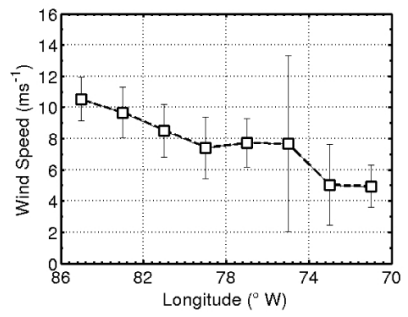

(b) Surface WS from the C-130

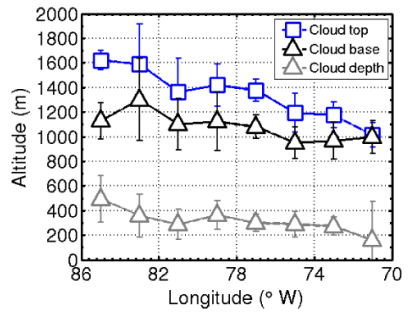

(c) Cloud Heights

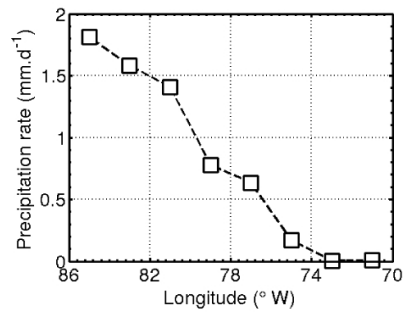

(d) Precipitation rate

Fig. 10. (a) ECMWF reanalysis of surface WS over the SEP during the VOCALS-REx period. The red dashed line marks the $20^{\circ} \mathrm{S}$ latitude. Averages for all $20^{\circ} \mathrm{S}$ missions are shown for (b) measured surface WS, (c) cloud top, cloud base and cloud depth, and (d) precipitation rate. Data are binned per $2^{\circ}$ of longitude.

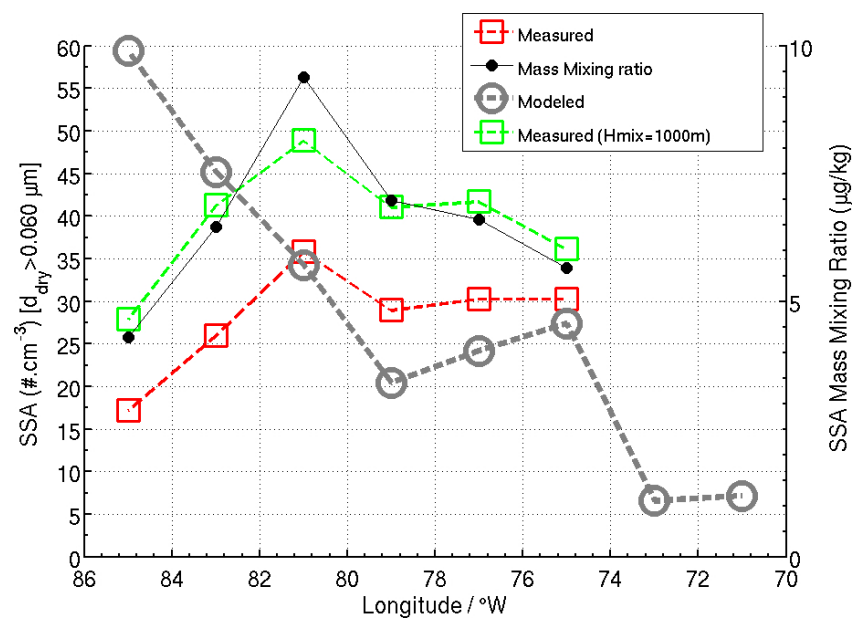

Fig. 11. Red squares represent the measured SSA concentrations along $20^{\circ} \mathrm{S}$. Measured SSA concentrations corrected for a constant mixing height are indicated with green squares and modeled SSA concentrations with gray circles. Black dots represent the mass mixing ratio of SSA to dry air at $20^{\circ} \mathrm{C}$. SSA data are missing east of $75^{\circ} \mathrm{W}$ where pollution was present and our clean air thresholds were never satisfied.

comparisons with GNI samples (see Sect. 2.2), to obtain the expected SSA mass from our size distributions.

\subsection{Contribution to $\mathrm{CCN}$ concentrations}

In this section we estimate the contribution of SSA and ammonium sulfate aerosol to the total $\mathrm{CCN}$ concentration along $20^{\circ} \mathrm{S}$ for clean air.

In order to integrate our clean size distribution and access the $\mathrm{CCN}$, we first need to estimate critical supersaturations that occurred along $20^{\circ} \mathrm{S}$. In Sect. 3.2, we show that these supersaturations can be obtained from total size distribution using the Hoppel minimum and assuming that for clean air the total number of aerosol is dominated by ammonium sulfates. Figure 12a shows MBL unheated size distributions averaged with $2^{\circ}$ longitude bins along $20^{\circ} \mathrm{S}$. It can be seen that the Hoppel minimum position and width is slightly variable for each averaged size distribution. However, except for $85^{\circ} \mathrm{W}$, we can roughly estimate that the averaged Hoppel minimum is within the 0.06 and $0.08 \mu \mathrm{m}$ ranges, which correspond, using Eq. (1), to a critical supersaturation of 0.32 and $0.20 \%$, respectively. Over the remote ocean $\left(85^{\circ} \mathrm{W}\right)$, the Hoppel minimum is shifted to smaller sizes $\left(0.05 \mu \mathrm{m} \leq d_{\text {dry }} \leq 0.06 \mu \mathrm{m}\right)$ indicating higher critical supersaturations $\left(0.32 \leq \mathrm{SS}_{\text {critical }}(\%) \leq 0.42\right)$ for thicker clouds and in very clean air (Twohy et al., 2013). The large difference in height and width of the Hoppel minimum between 75 and $77^{\circ} \mathrm{W}$ indicates a difference in the intensity or amount of cloud processing.

With these critical supersaturation estimates for stratocumulus clouds along $20^{\circ} \mathrm{S}$, we can calculate the minimum sizes at which SSAs are CCN active. Using the relationship between supersaturations and dry sizes for SSA (Eq. 2), we found that $0.20 \%, 0.32 \%$ and $0.42 \%$ correspond to the minimum SSA sizes of $0.07 \mu \mathrm{m}, 0.05 \mu \mathrm{m}$ and $0.045 \mu \mathrm{m}$, respectively. The latter highlight the importance of resolving the ultrafine fraction of the SSA in order to correctly evaluate the contribution to the ambient $\mathrm{CCN}$ number for clean and thick stratocumulus.

Hence, we now integrate our clean SSA, volatile and total aerosol size distributions to estimate the $\mathrm{CCN}$ number concentrations along $20^{\circ} \mathrm{S}$. The resulting number concentrations presented in Fig. 12b reveal that there is no obvious overall trend for the $\mathrm{CCN}$ variability for the $20^{\circ} \mathrm{S}$ latitude. However, similar to the SSA concentrations, we can assume that the decrease observed west of $81^{\circ} \mathrm{W}$ is due to the increase in precipitation offshore. Finally, based on Fig. 12b, we can estimate that SSA and volatile ammonium sulfate aerosol would 


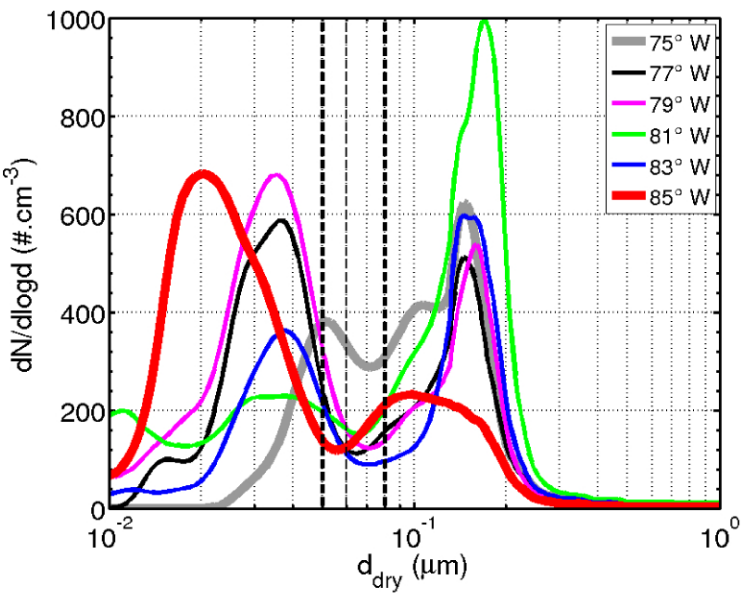

(a)

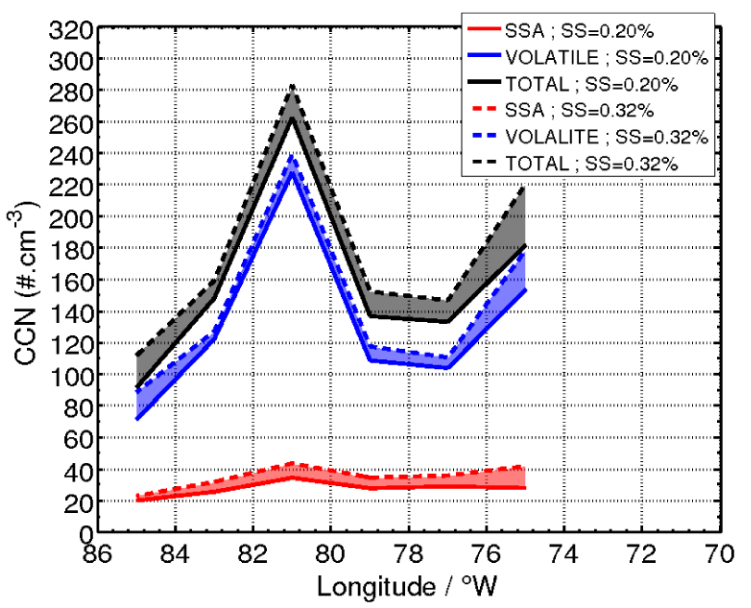

(b)

Fig. 12. (a) Mean size distributions of clean total number of aerosols along $20^{\circ} \mathrm{S}$. The dashed lines indicate the approximated position of the Hoppel minimum $\left(0.05 \mu \mathrm{m} \leq d_{\text {dry }} \leq 0.08 \mu \mathrm{m}\right)$. (b) Total CCN numbers (black), volatile CCN numbers (blue), and SSA CCN numbers (red) along $20^{\circ} \mathrm{S}$. The supersaturations (SS) used to integrate the size distributions are 0.32 and $0.20 \%$, except for $85^{\circ} \mathrm{W}$ which are 0.32 and $0.42 \%$.

represent on average about 20 and $80 \%$, respectively, of the total CCN number under clean conditions along $20^{\circ} \mathrm{S}$.

However, this percentage varies with location, and at 81 and $75^{\circ} \mathrm{W}$ the SSA contributions to CCN become 14 and $17 \%$, respectively. This percentage is influenced not only by production and removal of SSA in the MBL, but also by the entrainment of nuclei from the FT (Clarke et al., 1998). As pointed out in Yoon and Brimblecombe (2002) and Clarke et al. (2006), aerosols entrained from the FT and the SSA injected at the sea surface may be the most important source of the clean MBL CCN. As stated earlier, our study focused upon the more common closed cell convection encountered along $20^{\circ} \mathrm{S}$ by excluding conditions indicative of pockets of open cells (POC) associated with enhanced drizzle and lower entrainment (Wood et al., 2011b). But a recent model study under POC conditions present in the same VOCALS-REx region (Kazil et al., 2011) and using the same source function used in this paper found that SSA production tended to dominate over FT entrainment as a source of new CCN in POCs. Our preliminary results show that SSAs would represent more than $30 \%$ of the $\mathrm{CCN}$ in the clean mature POC observed on 28 October 2008 during RF06. Hence, assessment of the relative contribution of SSA to CCN in any region will require reliable evaluation of the production flux, removal flux and entrainment flux appropriate to that region.

\section{Summary and conclusions}

Frequent mixing of the natural marine aerosols with anthropogenic emissions have made it difficult to estimate SSA numbers injected into the MBL. This study shows the importance of isolating clean air data using sensitive instrumentation like the SP2 and AMS. Coarse SSAs (sea salts) produced by wind-induced breaking waves dominate the scattering. We showed that clean MBL non-volatile ultrafine aerosols larger than $0.040 \mu \mathrm{m}$ varied directly with this coarse scattering aerosol, indicating that both size classes were SSAs. We also demonstrated a strong and similar relationship between the latter over the VOCALS-REx open ocean to that found for individual breaking waves during SEAS. This supports the use of the Clarke et al. (2006) SSA source function in GCMs for open-ocean SSA emissions at the sea surface with diameters larger $0.040 \mu \mathrm{m}$. These findings are particularly important in order to better represent the cloud droplet size distribution in stratocumulus clouds where particle nuclei as small as $0.055 \mu \mathrm{m}$ are shown to be present (Twohy et al., 2013).

Over the remote SEP, more intense drizzle is linked to removal of about half of the SSA predicted for the wind speeds measured there. This study shows that wet removal must be taken in account in order to properly model SSA number concentrations for a given wind speed. Regression between SSA and wind speed has always shown a lot of scatter (Lewis and Schwartz, 2004). Our data suggests that much of this is probably related to the range of variability in precipitation history for many of the ambient measurements. Finally, our findings show that along $20^{\circ} \mathrm{S}$, the MBL SSA accounts for less than $20 \%$ of the total CCN in clean air. This may be a lower limit of percentages that might be found in other regions exposed to similar wind speeds but less drizzle. 


\section{Appendix A}

\section{SSA concentration estimation in the MBL}

We assume that SSAs are instantaneously and uniformly mixed over the MBL after ejection at the sea surface. All parameters are assumed to be vertically and horizontally homogeneous both along-wind and cross-wind. We disregard effects due to entrainment, and the dilution of SSA is taken into account through the variations of the inversion height $\left(H_{\mathrm{MBL}}\right)$. We also neglect chemical reactions, growth, nucleation or coagulation processes and removal by precipitation. We focus on ultrafine SSAs which dominate total number concentration. This implies that the time required to remove the aerosols by dry deposition is long compared to the upward mixing flux of particles. According to the previous assumptions, temporal variation of SSA in the MBL is obtained using Eq. (A1) (for details, see Lewis and Schwartz (2004) and references therein).

$H_{\mathrm{MBL}} \cdot \frac{D N}{D t}=F_{\mathrm{int}}$

with $H_{\mathrm{MBL}}$ in $\mathrm{m}$ and $F_{\text {int }}$ in $\mathrm{cm}^{-2} \mathrm{~s}^{-1} . F_{\text {int }}$ is the total surface flux of SSAs calculated using Eq. (A2).

$$
F_{\text {int }}=\int_{d_{\text {dry }} \geq d_{\text {dry }}{ }_{\text {min }}} f_{\text {int }} \cdot D \log d_{\text {dry }}
$$

$f_{\text {int }}$ in $\mathrm{cm}^{-2} \mathrm{~s}^{-1} \mu \mathrm{m}^{-1}$ is the interfacial surface source function of SSA per dry diameter bin width obtained with Eq. (A3).

$f_{\text {int }}=W \cdot \frac{D E}{D \log d_{\text {dry }}}$

where $W=3.84 \times 10^{-6} \cdot U_{10}^{3.41}$ is the whitecap coverage surface area taken from Monahan et al. (1986) with $U_{10}$ the wind speed at $10 \mathrm{~m} . \frac{D E}{D \log d_{\text {dry }}}$ is the size dependent SSA source function per unit of whitecap from Clarke et al. (2006). Integrating Eq. (A1), the total number of SSA is given by Eq. (A4).

$N(t)=\frac{F_{\text {int }} \cdot t}{H_{\mathrm{MBL}} \cdot 100} \cdot 3600$

where $t$, in hours, is the time that the air mass spent over the sea.

Acknowledgement. The authors would like to thank the staff and crew of the NCAR C-130 aircraft and other VOCALS-REx personnel for their efforts in providing an in situ observational dataset. The National Center for Atmospheric Research is sponsored by the National Science Foundation. This work was supported by NSF award ATM-0745368, ONR award N00014-07-1-0031, and NASA awards NNX10AN78G and NNX10AM29G. SOEST contribution no. 8943 .

Edited by: B. Albrecht
References

Allen, G., Coe, H., Clarke, A. D., Bretherton, C., Wood, R., Abel, S. J., Barrett, P., Brown, P., George, R., Freitag, S., McNaughton, C., Howell, S., Shank, L., Kapustin, V., Brekhovskikh, V., Kleinman, L., Lee, Y.-N., Springston, S., Toniazzo, T., Krejci, R., Fochesatto, J., Shaw, G., Krecl, P., Brooks, B., McMeeking, G., Bower, K. N., Williams, P. I., Crosier, J., Crawford, I., Connolly, P., Allan, J. D., Covert, D., Bandy, A. R., Russell, L. M., Trembath, J., Bart, M., McQuaid, J. B., Wang, J., and Chand, D.: South East Pacific atmospheric composition and variability sampled along $20^{\circ} \mathrm{S}$ during VOCALS-REx, Atmos. Chem. Phys., 11, 5237-5262, doi:10.5194/acp-11-5237-2011, 2011.

Anderson, T., Covert, D., Marshall, S., Laucks, M., Charlson, R., Waggoner, A., Ogren, J., Caldow, R., Holm, R., Quant, F., Sem, G., Wiedensohler, A., Ahlquist, N., and Bates, T.: Performance characteristics of a high-sensitivity, three-wavelength, total scatter/backscatter nephelometer, J. Atmos. Ocean. Tech., 13, 967-986, doi:10.1175/15200426(1996)013<0967:PCOAHS>2.0.CO;2, 1996.

Andreae, M. and Raemdonck, H.: Dimethyl sulfide in the surface ocean and the marine atmosphere: a global view, Science, 221, 744-747, doi:10.1126/science.221.4612.744, 1983.

Ångström, A.: On the atmospheric transmission of sun radiation and on dust in the air, Geogr. Ann., 11, 156-166, 1929.

Bates, T., Quinn, P., Frossard, A., Russell, L., Hakala, J., Petäjä, T., Kulmala, M., Covert, D., Cappa, C., Li, S., Hayden, K. L., Nuaaman, I., McLaren, R., Massoli, P., Canagaratna, M. R., Onasch, T. B., Sueper, D., Worsnop, D. R., and Keene, W. C.: Measurements of ocean derived aerosol off the coast of California, J. Geophys. Res., 117, D00V15, doi:10.1029/2012JD017588, 2012.

Bigg, E. and Leck, C.: The composition of fragments of bubbles bursting at the ocean surface, J. Geophys. Res., 113, D11209, doi:10.1029/2007JD009078, 2008.

Blanchard, D.: Sea-to-air transport of surface active material, Science, 146, 3642, doi:10.1126/science.146.3642.396, 1964.

Blanchard, D. and Woodcock, A.: Bubble formation and modification in the sea and its meteorological significance, Tellus, 9, 145-158, 1957.

Bodhaine, B. and Deluisi, J.: An aerosol climatology of Samoa, J. Atmos. Chem., 3, 107-122, 1985.

Bretherton, C. S., Wood, R., George, R. C., Leon, D., Allen, G., and Zheng, X.: Southeast Pacific stratocumulus clouds, precipitation and boundary layer structure sampled along $20^{\circ} \mathrm{S}$ during VOCALS-REx, Atmos. Chem. Phys., 10, 10639-10654, doi:10.5194/acp-10-10639-2010, 2010.

Cavalli, F., Facchini, M., Decesari, S., Mircea, M., Emblico, L., Fuzzi, S., Ceburnis, D., Yoon, Y., O’Dowd, C D., Putaud, J. P., and Dell'Acqua, A.: Advances in characterization of size-resolved organic matter in marine aerosol over the North Atlantic, J. Geophys. Res., 109, D24215, doi:10.1029/2004JD005137, 2004.

Clarke, A. D.: Aerosol light absorption by soot in remote environments, Aerosol Sci. Tech., 10, 161-171, doi:10.1029/JC077i027p05255, 1989.

Clarke, A. D.: A thermo-optic technique for in-situ analysis of sizeresolved aerosol physicochemistry, Atmos. Environ., 25, 635644, doi:10.1016/0960-1686(91)90061-B, 1991. 
Clarke, A. D. and Kapustin, V.: The Shoreline Environment Aerosol Study (SEAS): a context for marine aerosol measurements influenced by a coastal environment and long-range transport, J. Atmos. Ocean. Tech., 20, 1351-1361, doi:10.1175/15200426(2003)020<1351:TSEASS > 2.0.CO;2, 2003.

Clarke, A. D., Varner, J., Eisele, F., Mauldin, R., Tanner, D., and Litchy, M.: Particle production in the remote marine atmosphere: cloud outflow and subsidence during ACE 1, J. Geophys. Res., 103, 16397-16409, doi:10.1029/97JD02987, 1998.

Clarke, A. D., Owens, S., and Zhou, J.: An ultrafine sea-salt flux from breaking waves: implications for cloud condensation nuclei in the remote marine atmosphere, J. Geophys. Res., 111, D06202, doi:10.1029/2005JD006565, 2006.

Craig, L.: Towards understanding of shatter artifacts in airborne sampling inlets: Analysis of aerosol-cloud measurements, Ph.D. thesis, Clarkson University, Clarkson University, Potsdam, New York, USA, 2012.

De Leeuw, G., Andreas, E., Anguelova, M., Fairall, C., Lewis, E., O'Dowd, C. D., Schulz, M., and Schwartz, S.: Production flux of sea spray aerosol, Rev. Geophys., 49, RG2001, doi:10.1029/2010RG000349, 2011.

Garreaud, R. and Muñoz, R.: The low-level jet off the west coast of subtropical South America: structure and variability, Mon. Weather Rev., 133, 2246-2261, doi:10.1175/MWR2972.1, 2005.

Gunn, R. and Kinzer, G.: The terminal velocity of fall for water droplets in stagnant air, J. Atmos. Sci., 6, 243-248, doi:10.1175/1520-0469(1949)006<0243:TTVOFF>2.0.CO;2, 1949.

Heintzenberg, J., Covert, D. C., Van Dungenen, R.: Size distribution and chemical composition of marine aerosols: a compilation and review, Tellus B, 52, 1104-1122, doi:10.1034/j.16000889.2000.00136.x, 2000.

Hoppel, W., Frick, G., and Larson, R.: Effect of nonprecipitating clouds on the aerosol size distribution in the marine boundary layer, Geophys. Res. Lett., 13, 125-128, doi:10.1029/GL013i002p00125, 1986.

Hoppel, W., Frick, G., and Fitzgerald, J.: Deducing droplet concentration and supersaturation in marine boundary layer clouds from surface aerosol measurements, J. Geophys. Res.-Atmos., 101, 26553-26565, doi:10.1029/96JD02243, 1996.

Kazil, J., Wang, H., Feingold, G., Clarke, A. D., Snider, J. R., and Bandy, A. R.: Modeling chemical and aerosol processes in the transition from closed to open cells during VOCALS-REx, Atmos. Chem. Phys., 11, 7491-7514, doi:10.5194/acp-11-74912011, 2011

Kiehl, J. and Rodhe, H.: Modeling geographical and seasonal forcing due to aerosols, in: Aerosol forcing of climate, J. Wiley and Sons, NY, USA, 281-296, 1995.

Köhler, H.: The nucleus in and the growth of hygroscopic droplets, T. Faraday Soc., 32, 1152-1161, 1936.

Leck, C. and Bigg, E.: Biogenic particles in the surface microlayer and overlaying atmosphere in the central Arctic Ocean during summer, Tellus B, 57, 305-316, doi:10.1111/j.16000889.2005.00148.x, 2005.

Lewis, E. and Schwartz, S.: Sea Salt Aerosol Production: Mechanisms, Methods, Measurements and Models: A Critical Review, Vol. 152, Geophys. Monogr. Ser., Amer. Geophysical Union, Washington, DC, doi:10.1029/GM152, 2004.
Mårtensson, E., Nilsson, E., De Leeuw, G., Cohen, L., and Hansson, H.: Laboratory simulations and parameterization of the primary marine aerosol production, J. Geophys. Res., 108, 21562202, doi:10.1029/2002JD002263, 2003.

McMurry, P. H.: A review of atmospheric aerosol measurements, Atmos. Environ., 34, 1959-1999, doi:10.1016/S13522310(99)00455-0, 2000.

McNaughton, C. S., Clarke, A. D., Howell, S. G., Pinkerton, M., Anderson, B., Thornhill, L., Hudgins, C., Winstead, E., Dibb, J. E., Scheuer, E., and Maring, H.: Results from the DC-8 Inlet Characterization Experiment (DICE): airborne versus surface surface sampling of mineral dust and sea salt aerosols, Aerosol Sci. Tech., 41, 136-159, doi:10.1080/02786820601118406, 2007.

Mechem, D. B., Robinson, P., and Kogan, Y. L.: Processing of cloud condensation nuclei by collision-coalescence in a mesoscale model, J. Geophys. Res.-Atmos., 111, D18, doi:10.1029/2006JD007183, 2006.

Monahan, E. C., Spiel, D., and Davidson, K.: A model of marine aerosol generation via whitecaps and wave disruption, in: Oceanic Whitecaps and Their Role in Air-Sea Exchange Processes, Springer, New York, 167-193, 1986.

Murphy, D., Anderson, J., Quinn, P., McInnes, L., Brechtel, F. Kreidenweis, S., Middlebrook, A., Posfai, M., Thomson, D., and Buseck, P.: Influence of sea-salt on aerosol radiative properties in the Southern Ocean marine boundary layer, Nature, 392, 62-65, doi:10.1038/32138, 1998.

Niedermeier, D., Wex, H., Voigtländer, J., Stratmann, F., Brüggemann, E., Kiselev, A., Henk, H., and Heintzenberg, J.: LACISmeasurements and parameterization of sea-salt particle hygroscopic growth and activation, Atmos. Chem. Phys., 8, 579-590, doi:10.5194/acp-8-579-2008, 2008

O’Dowd, C. D., Smith, M. H., Consterdine, I. E., Lowe, J A.: Marine aerosol, sea-salt, and the marine sulphur cycle: a short review, Atmos. Environ., 31, 73-80, doi:10.1016/S13522310(96)00106-9, 1997.

O’Dowd, C. D., Facchini, M., Cavalli, F., Ceburnis, D., Mircea, M., Decesari, S., Fuzzi, S., Yoon, Y., and Putaud, J.: Biogenically driven organic contribution to marine aerosol, Nature, 431, 676680, doi:10.1038/nature02959, 2004.

Peters, T. and Leith, D.: Concentration measurements and counting efficiency of the aerodynamic particle sizer 3321, J. Aerosol Sci., 34, 627-634, doi:10.1016/S0021-8502(03)00030-2, 2003.

Prospero, J. and Carlson, T.: Vertical and areal distribution of Saharan dust over the western equatorial North Atlantic Ocean, J. Geophys. Res., 77, 5255-5265, doi:10.1029/JC077i027p05255, 1972.

Prospero, J. and Savoie, D.: Effect of continental sources on nitrate concentrations over the Pacific Ocean, Nature, 339, 687689, doi:10.1038/339687a0, 1989.

Ramanathan, V., Crutzen, P., Kiehl, J., and Rosenfeld, D.: Aerosols, climate, and the hydrological cycle, Science, 294, 2119-2124, doi:10.1126/science.1064034, 2001.

Rogers, R.: A short course in cloud physics, in: A Short Course in Cloud Physics, Pergamon Press, Elmsford, Oxford, NY, USA, 227 pp., 1979.

Savole, D. and Prospero, J.: Particle size distribution of nitrate and sulfate in the marine atmosphere, Geophys. Res. Lett., 9, 12071210, doi:10.1029/GL009i010p01207, 1982. 
Schuster, G., Dubovik, O., and Holben, B.: Angstrom exponent and bimodal aerosol size distributions, J. Geophys. Res., 111, D07207, doi:10.1029/2005JD006328, 2006.

Schwarz, J., Gao, R., Fahey, D., Thomson, D., Watts, L., Wilson, J., Reeves, J., Darbeheshti, M., Baumgardner, D., Kok, G. L., Chung, S. H., Schulz, M., Hendricks, J., Lauer, A., Kärcher, B., Slowik, J. G., Rosenlof, K. H., Thompson, T. L., Langford, A. O., Loewenstein, M., and Aikin, K. C.: Single-particle measurements of midlatitude black carbon and light-scattering aerosols from the boundary layer to the lower stratosphere, J. Geophys. Res., 111, 2156-2202, doi:10.1029/2006JD007076, 2006.

Sellegri, K., O'Dowd, C. D., Yoon, Y., Jennings, S., and de Leeuw, G.: Surfactants and submicron sea spray generation, J. Geophys. Res., 111, D22215, doi:10.1029/2005JD006658, 2006.

Shank, L. M., Howell, S., Clarke, A. D., Freitag, S., Brekhovskikh, V., Kapustin, V., McNaughton, C., Campos, T., and Wood, R.: Organic matter and non-refractory aerosol over the remote Southeast Pacific: oceanic and combustion sources, Atmos. Chem. Phys., 12, 557-576, doi:10.5194/acp-12-5572012, 2012.

Shinozuka, Y., Clarke, A. D., Howell, S., Kapustin, V., and Huebert, B.: Sea-salt vertical profiles over the Southern and tropical Pacific oceans: microphysics, optical properties, spatial variability, and variations with wind speed, J. Geophys. Res., 109, D24201, doi:10.1029/2004JD004975, 2004.

Snider, J. R., Guibert, S., Brenguier, J. L., and Putaud, J. P.: Aerosol activation in marine stratocumulus clouds: 2. Köhler and parcel theory closure studies, J. Geophys. Res., 108, D15, doi:10.1029/2002JD002692, 2006.

Stevens, B. and Feingold, G.: Untangling aerosol effects on clouds and precipitation in a buffered system, Nature, 461, 607-613, doi:10.1038/nature08281, 2009.

Tang, I. N., Tridico, A. C., and Fung, K. H.: Thermodynamic and optical properties of sea salt aerosols, J. Geophys. Res., 102, 23269-23275, 1997.

Twohy, C. H., Anderson, J. R., Toohey, D. W., Andrejczuk, M., Adams, A., Lytle, M., George, R. C., Wood, R., Saide, P., Spak, S., Zuidema, P., and Leon, D.: Impacts of aerosol particles on the microphysical and radiative properties of stratocumulus clouds over the southeast Pacific Ocean, Atmos. Chem. Phys., 13, 25412562, doi:10.5194/acp-13-2541-2013, 2013.

Twomey, S.: Pollution and the planetary albedo, Atmos. Environ., 8, 1251-1256, doi:10.1016/0004-6981(74)90004-3, 1974.

Vaishya, A., Jennings, S. G., and O'Dowd, C. D.: Seasonal variation of the aerosol light scattering coefficient in marine air of the northeast atlantic, Adv. Meteorol., 2011, 170490, doi:10.1155/2011/170490, 2011.

Wang, H. and John, W.: Particle density correction for the aerodynamic particle sizer, Aerosol Sci. Tech., 6, 191-198, doi:10.1080/02786828708959132, 1987.

Wang, Z., Wechsler, P., Kuestner, W., French, J., Rodi, A., Glover, B., Burkhart, M., and Lukens, D.: Wyoming Cloud Lidar: instrument description and applications, Opt. Express, 17, 13576-13587, doi:10.1364/OE.17.013576, 2009.
Wilson, J. and Liu, B.: Aerodynamic particle size measurement by laser-Doppler velocimetry, J. Aerosol Sci., 11, 139-150, doi:10.1016/0021-8502(80)90030-0, 1980.

Wood, R.: Rate of loss of cloud droplets by coalescence in warm clouds, J. Geophys. Res.-Atmos., 111, D21205, doi:10.1029/2006JD007553, 2012.

Wood, R., Comstock, K., Bretherton, C., Cornish, C., Tomlinson, J., Collins, D., and Fairall, C.: Open cellular structure in marine stratocumulus sheets, J. Geophys. Res., 113, D12207, doi:10.1029/2007JD009371, 2008.

Wood, R., Bretherton, C. S., Leon, D., Clarke, A. D., Zuidema, P., Allen, G., and Coe, H.: An aircraft case study of the spatial transition from closed to open mesoscale cellular convection over the Southeast Pacific, Atmos. Chem. Phys., 11, 2341-2370, doi:10.5194/acp-11-2341-2011, 2011a.

Wood, R., Mechoso, C. R., Bretherton, C. S., Weller, R. A., Huebert, B., Straneo, F., Albrecht, B. A., Coe, H., Allen, G., Vaughan, G., Daum, P., Fairall, C., Chand, D., Gallardo Klenner, L., Garreaud, R., Grados, C., Covert, D. S., Bates, T. S., Krejci, R., Russell, L. M., de Szoeke, S., Brewer, A., Yuter, S. E., Springston, S. R., Chaigneau, A., Toniazzo, T., Minnis, P., Palikonda, R., Abel, S. J., Brown, W. O. J., Williams, S., Fochesatto, J., Brioude, J., and Bower, K. N.: The VAMOS Ocean-Cloud-Atmosphere-Land Study Regional Experiment (VOCALS-REx): goals, platforms, and field operations, Atmos. Chem. Phys., 11, 627-654, doi:10.5194/acp-11-627-2011, $2011 b$.

Wood, R., Leon, D., Lebsock, M., Snider, J., and Clarke, A. D.: Precipitation driving of droplet concentration variability in marine low clouds, J. Geophys. Res.-Atmos., 117, 2156-2202, doi:10.1029/2012JD018305, 2012.

Woodcock, A.: Note concerning human respiratory irritation associated with high concentrations of plankton and mass mortality of marine organisms, J. Mar. Res., 7, 56-62, 1948.

Yang, Q., Gustafson Jr., W. I., Fast, J. D., Wang, H., Easter, R. C., Wang, M., Ghan, S. J., Berg, L. K., Leung, L. R., and Morrison, H.: Impact of natural and anthropogenic aerosols on stratocumulus and precipitation in the Southeast Pacific: a regional modelling study using WRF-Chem, Atmos. Chem. Phys., 12, 8777-8796, doi:10.5194/acp-12-8777-2012, 2012.

Yoon, Y. J. and Brimblecombe, P.: Modelling the contribution of sea salt and dimethyl sulfide derived aerosol to marine CCN, Atmos. Chem. Phys., 2, 17-30, doi:10.5194/acp-2-17-2002, 2002.

Zhou, J.: Hygroscopic properties of atmospheric aerosol particles in various environments, Ph.D. thesis, Lund University, Lund, Sweden, 2001.

Zhou, J., Swietlicki, E., Berg, O., Aalto, P., Hameri, K., Nilsson, E., and Leck, C.: Hygroscopic properties of aerosol particles over the central Arctic Ocean during summer, J. Geophys. Res.Atmos., 106, 2156-2202, doi:10.1029/2000JD900426, 2001. 